\title{
OYSTERS AND DISEASE
}

An Account of certain Observations upon the Normal and

Pathological Histology and Bacteriology of

THe Oyster And Other Shellfish.

BY

W. A. HERDMAN, D.Sc., F.R.S.,

Professor of Zoology in University College, liverpool, and Honorary Director of Scientific Work to the LanCashire Sea-Fisheries Committee;

AND

RUBERT BOYCE, M.B.,

Professor of Pathology in University College, Liveryool, and Bacteriologist to the City of Liverpool.

With Eight Plates.

Price 7s. 6d. nett.

LONDON :

GEORGE PHILIP \& SON, 32 FLEET STREET, E.C. LIVERPOOL: PHILIP, SON \& NEPHEW, $45-5 \mathrm{I}$ SOUTH CASTLE STREET.

1899. 


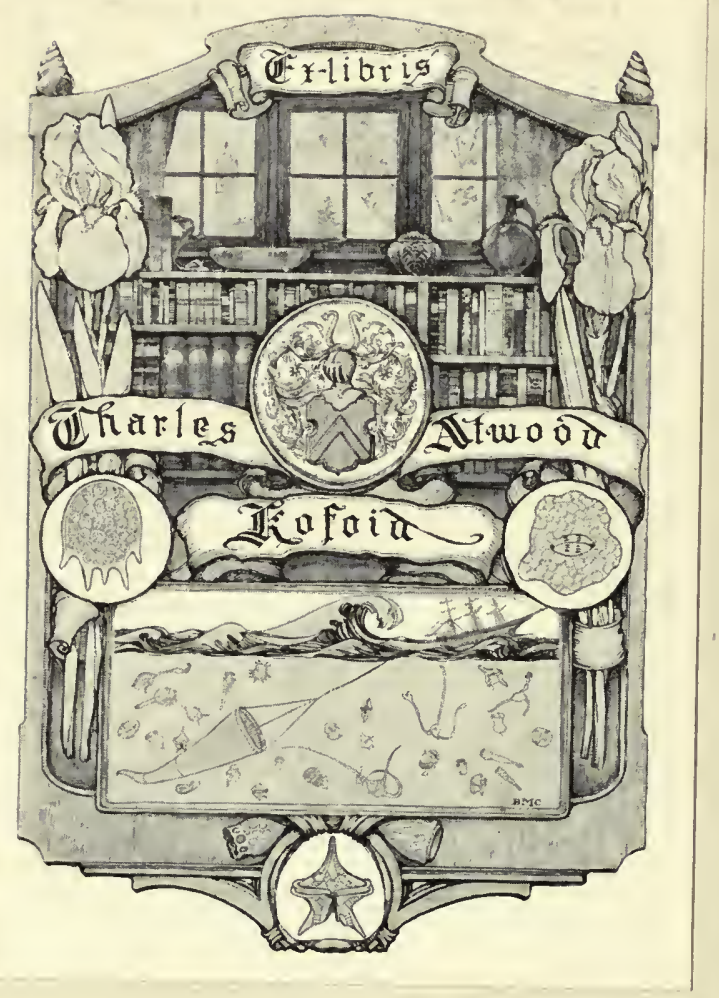




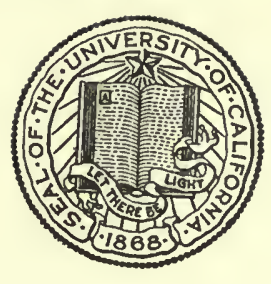

THE LIBRARY

OF

THE UNIVERSITY

OF CALIFORNIA

PRESENTED BY

PROF. CHARLES A. KOFOID AND

MRS. PRUDENCE W. KOFOID 

OYSTERS AND DISEASE 
Digitized by the Internet Archive in 2008 with funding from Microsoft Corporation 


\section{LANCASHIRE SEA-FISHERIES MEMOIR-NO. I.}

\section{OYSTERS AND DISEASE}

An Account of Certain Observations upon the Normal and

Pathological Histology and Bacteriology of

the Oyster And other Shellfish.

BY

W. A. HERDMAN, D.Sc., F.R.S.,

Professor of Zoology in University College, liverpool, and Honorary Director of Scientific Work to the Lancashire Sea-Fisheries Committee;

AND

RUBERT BOYCE, M.B.,

Professor of Pathology in University College, Liverpool, and Bacteriologist to the City of liverpool.

With Eight Plates.

LONDON :

GEORGE PHILIP \& SON, 32 FLEET STREET, E.C.

LIVERPOOL: PHILIP, SON \& NEPHEW, 45-5I SOUTH CASTLE STREET.

1899. 



\section{Dedícatíon.}

To

J O H N F E L L, Esq., J.P. and D.L.,

Chairman of the Lancashire Sea-Fisheries Committee.

Dear Mr. Fell,

We think it most appropriate, and it is a pleasure to us, that this First Lancashire Sea-Fisheries Memoir should be dedicated to you, the First Chairman of the Committee under whose auspices a large proportion of this and other scientific work on Fisheries' questions has been carried on.

It is widely known in Lancashire that the formation of our Local Sea-Fisheries Committee was largely due to your personal energy and infuence, and that to your wise guidance during the first decade of its existence is due in great measure the success of its administration, and its present commanding position. But it may be well to point out. what is not so generally known, that from the first you recognised that the Sea-Fisheries form a department of general Marine Biology, and that sound legislation and administration must be founded on the results of scientific and other correct practical investigations.

W. A. Herdman.

University Coliege, Liverpool, R. Boyce.

July, 1899. 



\section{O N T E N T S.}

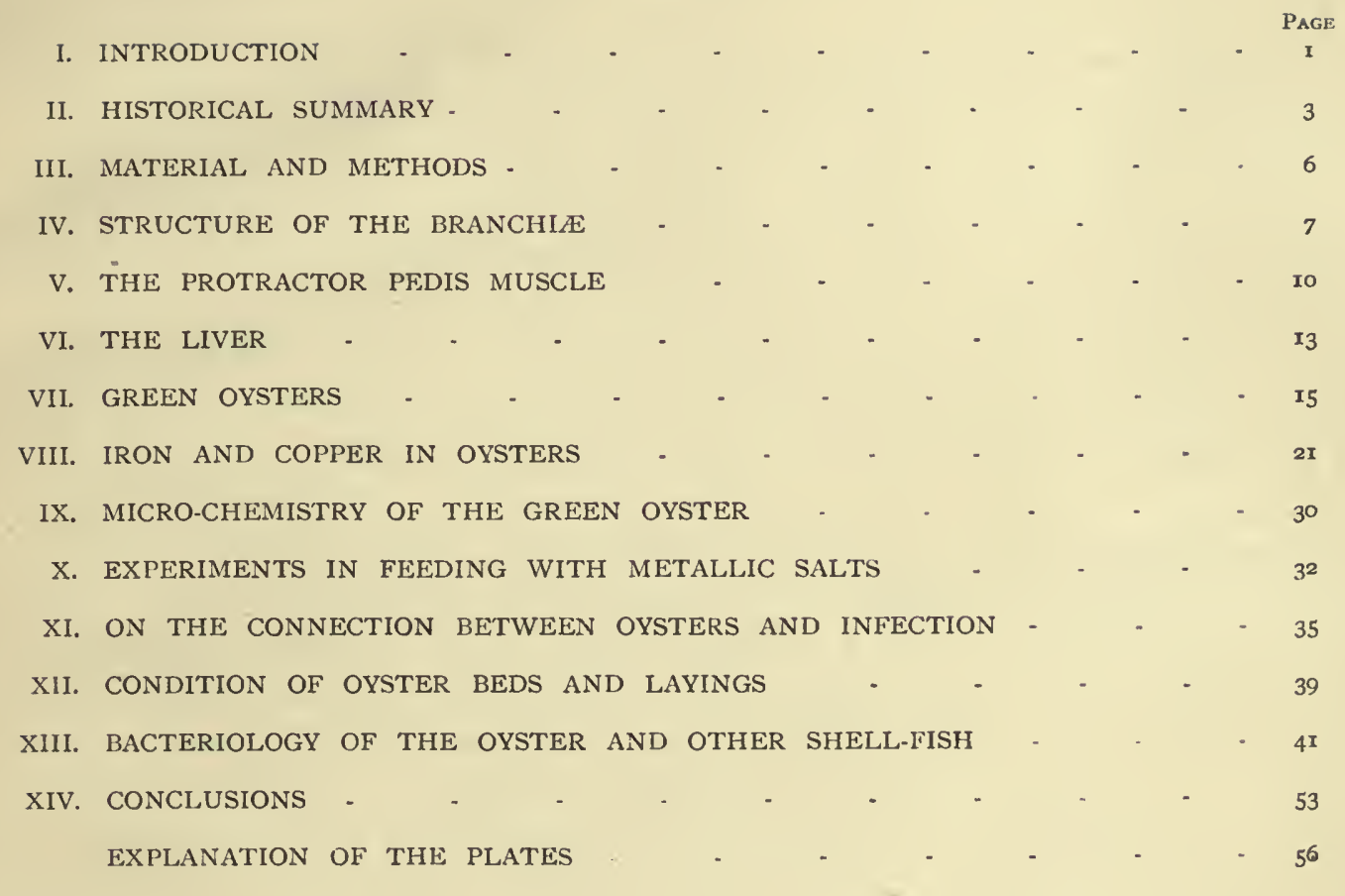





\section{OYSTERS AND DISEASE.}

\section{I.-INTRODUCTION.}

This research was commenced three years ago, and has been carried on intermittently in the intervals of other work. One of us (W. A. H.) had been working for some years previously at Fishery questions for the Lancashire Sea-Fisheries Committee, and so had become cognisant of the methods of growing and bedding Oysters on our coasts, of their variations in condition and colour, and of the want of exact knowledge as to their connection with disease. As this was clearly a matter of combined Natural History and Bacteriology, he proposed to his colleague (R. B.) that they should undertake a joint investigation of the structure and life-conditions of the Oyster in healthy and unhealthy environments-a matter of importance both for the Oyster industries and for public health.

A preliminary paper on the plan of work and on the first experiments was laid before Section D. (Zoology and Physiology) at the Ipswich meeting of the British Association (September, 1895). This led to the formation of a small Committee to carry on the work, with the help of a grant of $£ 40$; and interim reports were submitted at the Liverpool (I896) and Toronto (1897) meetings. The final report of that Committee was given to the British Association at Bristol last autumn.

In these reports, necessarily brief and without illustrations, it has only been possible to give a summary of results; and, in the summer of 1897 , one section of the subject-the presence of copper in the leucocytes of certain Oysters-was treated by us in a preliminary manner in a short communication to the Royal Society.* We propose now to give a full account of the evidence upon which our various conclusions, some of which were announced in these preliminary reports, are based, along with a discussion of our results and those of other workers, both from the purely scientific and also from the Fisheries and the Sanitary points of view.

One member of our British Association Committee, Dr. Charles Kohn, Lecturer in Chemistry at University College, Liverpool, has given us considerable help from time to time in discussing with us the chemical aspects of the work, and in making analyses of different kinds of Oysters. We have also had the advantage of advice from our 
colleague Professor Sherrington, also a member of the Committee. Our friend Dr. P. P. C. Hoek, Scientific Fisheries Adviser to the Dutch Government, visited our laboratories in February, 1897, for the purpose of seeing our work and its bearings upon Dutch Oyster culture. He went through all our results with us, and took part in an examination at that time of various kinds of green oysters. We have recently (June, I 898) had the opportunity of discussing fully the histo-chemical reactions with Professor Macallum, of Toronto, whose opinion on some points will be referred to further on.

We desire to acknowledge, finally, the help we have received, in what has been a very laborious investigation, because of the large numbers of animals dealt with and the very different lines of work involved, from the Assistants in our laboratories. We would thank especially Mr. Andrew Scott and Mr. James Johnstone, "Fisheries" Assistants in the Zoological Laboratory; and Dr. Dutton, Dr. Christophers, and Dr. Abram, in the Pathological Department. Some of the figures in our plates have been drawn, under our direction, by Mr. Johnstone, and others by Mr. Fisher of the Pathological Department. The rest are our own.

\section{LIVERPOOL,}

December, 1898. 


\section{II.-HISTORICAL SUMMARY.}

A considerable part of our work has dealt with "greenness" in oysters of different kinds-a subject on which many contradictory statements have been made, and which has a curiously involved history.

In I 866, Mr. A. W. E. O'Shaughnessy* gave an excellent account of our knowledge of the "greening" of oysters up to that date. He showed how M. Benjamin Gaillon, in I 820 , $†$ observed the blue diatom Navicula fusiformis, variety ostrearia-which he then called Vibrio ostrearius-in the "Claires" of the Oyster Merchants at Marennes, \&c., in France, and attributed to it the dark bluish green tint of the gills, palps, intestine, and liver of the cultivated oyster. He also discussed the observations of Valenciennes, Dumas, Bizio, Buckland, and others; and cited some historical cases of poisoning supposed to be due to the presence of copper in large quantities in green oysters. As these earlier observations are discussed also by Professor Ray Lankester in his important paper in 1885 , $\ddagger$ they need not be further alluded to here. But we must add to Lankester's record by referring to Puységur, $\S$ who, in I880, gave an account of certain experiments, in which he stated that he had succeeded in turning oysters green in some few hours by feeding them upon the diatom Navicula ostrearia. It has also been shown experimentally by Bornet, Decaisne, and others, that white oysters can be greened rapidly by keeping them in clean soup plates and feeding them with water containing the Navicula. These interesting experiments were carried out at Le Croisic, in Brittany, and were afterwards repeated in Paris, and the result seems entirely opposed to the old suggestion, due originally to Coste, $\|$ in $\mathbf{I} 86 \mathrm{I}$, that iron salts in the soil at the bottom of the "Claire" are the cause of the greening, which suggestion was alluded to again more than twenty years ago by Bouchon-Brandely, $\uparrow$ and has quite recently been revived by Carazzi** at Spezia. Moreover, Bornet and Ad. Chatin have shown that in the parks at Sable d'Olonne the greening may be suddenly manifested where the oysters had previously remained white, under circumstances where the microscopic fauna and flora of the water may well have changed, but where the floor of the park has undoubtedly remained the same. Finally, Mr. E. Newman, manager of the Colne River Oyster Beds, has shown us that when the Algæ (common Cyanophyceæ) in his ponds get into a certain condition, he can convert the ordinary colourless Colchester "native" into a green-gilled oyster in 24 hours.

* Ann. and Mag. Nat. Hist., vol. XVIII., p. 22I

¥ Quart. Journ. Microsc. Sci., vol. XXVI., p. 7 I.

† Journ. de Physique, tome XCI., p. 222.

II Voyage d'Exploration sur le littoral de la France, \&c.

$\S$ Revue Maritime et Coloniale, 1880.

T Rapport au Ministre de la Marine relatif à l'Ostréiculture, \&c., Paris, 18;6.

** Mitth. Zool. Stat. Neapel. 1896, p. $3^{81}$. 
Ryder in America was also, in I880, investigating the greening of oysters, with much the same results as those of Puységur. He went a step further, however, and showed that the colouring matter was taken up by the amœboid blood-cells, and that these wandering cells containing the pigment were to be found in the heart, in some of the blood vessels, and in aggregations in "cysts" under the surface epithelium of the body.* He describes the colour (in the ventricle) as a "delicate pea-green," and states that it is not chlorophyll or diatomine: he suggests that it may be phycocyanine or some allied substance. This is undoubtedly the same green in the leucocytes and the heart which we now find to contain a salt of copper.

In 1885 , Ray Lankester $†$ gave a useful summary of some of the earlier papers, and discussed the main questions concerned. Moreover, he investigated the gills of the green oyster histologically, and described and figured for the first time cells laden with green granules which occur in the epithelium of the gills and labial palps. He showed that such cells are also present in the common oyster, where, however, they are not green, and that these or similar cells may be found also wandering over the surface of the gills. He considered these as "secretion" cells, but those on the surface are clearly the same structures which Ryder a few years before had found in the blood, and are therefore leucocytes. Lankester found the Navicula in the intestine of the green oyster; and he reasserted that there was no copper and no iron in the diatom's refractory blue pigment-which he described under the name "Marennin," and identified with the pigment of the large green "secretion cells" of gills and labial palps.

This explanation of the "greening" has since been confirmed by Joannes Chatin, who has also described more fully the histology of the large green granular cells of the gills, which he called "macroblasts." He showed that in brown oysters these same cells contain brown granules.

Lankester's amœboid cells, laden with green granules and moving over the surface of the gill, are almost certainly leucocytes or amobocytes which have wandered out from the body through the surface epithelium : such diapedeses are probably of frequent occurrence in the Mollusca. Pelseneer $\$$ (1892) and De Bruynell (1895), in recent papers, consider that these cells act as phagocytes-which is quite probable-and we understand that Lankester would now accept this view himself. Dr. D. Carazzi of Spezia, however, who has recently (I896 and I897) written several rather controversial papers on the subject, will have none of this, and states that the diapedesis is entirely a pathological phenomenon. He attributes the green colour to the cylindrical epithelium solely, and not to the "secretion cells," or "macroblasts," and regards the Marennin as a nutrient

* Ryder's papers are found scattered through the U.S. Fish Commission publications from 1882 onwards.

† Quart. Journ. Micros. Sci., vol. XXVI., p. 71 .

$\ddagger$ Comptes-rendus, CXVI., p. 264 (1893); and CXX., p. 884 (1895).

$\S$ Bull. Soc. Malacol. Belg., t. XXVII., p. Ixii. \| Arch. de Biologie, t. XIV., p. 16I.

T See Nature for 9th May, 1895, p. 28. Joannes Chatin, in a more recent noie (Comptes-rendus, Feb. 24, 1896) adopts a modified view that the phagocytes are connective-tissue corpuscles distinct both from the blood-cells (leucocytes) and the fixed macroblasts. 
material on its way inwards from the surface to the liver. However, as Carazzi contradicts* almost everything both morphological and physiological that has been stated by previous workers on the oyster-Lankester, J. Chatin, Pelseneer, De Bruyne, Ryder, and ourselves alike-it is a little difficult to meet him seriously and to find patience to deal in detail with all his remarkable statements. Some of the points he raises, however, and of his so-called errors in the work of others, will be discussed further on in this paper.

There are many other papers upon both the structure and the physiology of the oyster-and especially the green Marennes oyster-which we have not referred to above. A very complete bibliography of the subject was published by the United States Fish Commission in 1892 , and so we have only considered it necessary to discuss the papers which we have found useful, or which for any reason seemed to require our attention. Previous work on the Bacteriology of Oysters, and the supposed connection with disease in Man, we shall discuss in the latter part of this paper.

* Mitth. Zool. Stat. Neapel. Bd. XII. ; Internat. Monatsschrift fur Anat. u. Physiol. Bd. XIV., \&c. 


\section{III.-MATERIAL AND METHODS.}

We have used three distinct species of oyster, and many local variaties, or races, from various parts of the European and American coasts. The species are the following :-

I. Ostrea edulis, Linn., the common edible oyster of North-west Europe, the species to which our "Natives," "Deep-sea oysters," "Rock oysters," "Pandores," and many other kinds from our own and neighbouring coasts belong. We have had samples of these from Colchester, Pyefleet, Mersea, Roach River, Leigh, Plymouth, Falmouth, Jersey, Wales, Isle of Man, Lancashire, the Scheldt, Nieuport, Spezia, and the West Coast of France.

2. Ostrea virginica, Gm., the American oyster : very commonly "laid," "bedded," or stored on various parts of our coast. We have had samples of "East Rivers," "Sounds," and "Blue Points," direct from America to Liverpool ; and of those that have been bedded in this country for longer or shorter periods, from Dublin, Carlingford, Fleetwood, Brightlingsea, Leigh, Falmouth, and the Menai Straits.

3. Ostrea (Gryphaea) angulata, Lamk., the Portuguese oyster of Southern and Western Europe. We have had samples of this from Arcachon in the Southwest of France, and from Falmouth, Leigh, and the estuary of the Colne.*

All the oysters have been examined in the first place alive, and their characters noted: coloured sketches have been made of many. In some cases the gills and other parts have been examined fresh, in teased and pressure preparations; but in all cases pieces have also been fixed, preserved, and sectioned. We have employed a variety of methods. Some gills and pieces of liver and intestine have been frozen in gum and cut at once with the freezing microtome, in order to have sections of the fresh tissue unstained for comparison with the sections which have undergone treatment with re-agents.

We have obtained the best results from our sections of mantle lobes, gills and viscera which had been fixed in corrosive sublimate and acetic acid, washed with alcohol, and then put through increasing strengths of alcohol, and finally iodine dissolved in 90 per cent. alcohol, cleared in either turpentine or xylol, imbedded in paraffine, cut with the Cambridge Rocking microtome, stained in eosine and hæmatoxylon, and mounted in balsam. Some of our preparations were fixed in 5 per cent. solution of formol in place of corrosive and acetic. The washing with iodine and alcohol was sometimes deferred until the sections were on the slide, previous to staining.

The Histo-Chemical and Bacteriological methods will be stated below in Sections IX. and XIV. respectively.

* We are much indebted to several gentlemen for kindly taking trouble to supply us with the special kinds of Oysters we desired. We would especially thank Charles Petrie, Esq., C.C., and Geo. T. G. Musson, Esq., of Liverpool ; Rupert Vallentin, Esq., of Falmouth; Dr. P. P. C. Hoek, of Helder; Dr. J. G. de Man, of Ierseke, and Dr. J. M. Bottemanne, of Bergen-op-Zoom, in Holland; and also Dr. Murie, and Mr. James Hornell of Jersey. 


\section{IV.-THE STRUCTURE OF THE BRANCHIÆ.}

\section{(See Plate I.)}

Figures 2 to 5 on Plate I. show the normal structure or the gill in a healthy oyster, whether white or green. The oyster has the four great flattened branchial folds (P1. I., Fig. I, br.), an external and an internal on each side, characteristic of Lamellibranch Molluscs. On account, however, of the absence of the foot, the two internal branchiæ come into close proximity in the middle line along their whole length, and so all four gills lie closely superposed along the ventral and posterior edges of the body: they encircle about two-thirds of the circumference. The branchiæ occupy about onethird of the superficial area exposed on removal of a shell, and make up from one-third to one-sixth of the total bulk of the body. Physiologically they are one of the most important and constantly active organs of the body, as respiration is certainly not their sole, probably not their chief, function. They cause, by their ciliated epithelium, that powerful and all important current of water which carries food as well as oxygen into the body and removes all waste products.

The gill filaments constituting the gills hang side by side; but even those of one gill lamella, or surface, are not all in the same vertical plane, as the row of filaments is plicated to form alternate crests and troughs (P1. I., Fig. 2). The crests or projections form ridges visible to the eye, of which there are about one hundred or rather more on the surface of a gill; and as each such crest has at least Io (sometimes I5) gill filaments, there must be over I,000 filaments on each surface of each gill, or, say, 8,000 to 10,000 in all. The transverse sections shown in Figures 2 and 3 show clearly the arrangement of the filaments in projecting crests on both surfaces of each gill. Concrescence (or inter-filamentar junctions) takes place to various degrees between neighbouring filaments, and consequently the blood channels form a network of varying arrangement in different parts, and the water passages are in many places partially occluded. In Figure 3, $a$ indicates a spot where the filaments retain their primitive independence; while $b$ shows complete concrescence between the 12 filaments of one crest. This Figure and the other transverse sections show also the arrangement of the skeletal elements in the connective tissue of the filaments. Each filament has two longitudinally running skeletal bars, formed of condensed fibrillated connective tissue, roughly fusiform in section, and lying just under the epithelium on the external face of the filament (Figs. 4 and 5). At the bottom of each trough we find a single enlarged filament, with a modified pair of skeletal bars of much greater size, and of triangular form in cross-section. These pairs of larger bars in each trough are conspicuous objects in low-power views (see Figs. 2, 3). 
Each gill filament has the branchial epithelium (ectoderm) on its outer surface, and the blood channel, lined by a thin layer of connective tissue, in its interior (Fig. 4). The skeletal bars lie between the epithelium and the connective tissue; the blood space contains here and there leucocytes, rounded or stellate, for the most part colourless, blood cells. There are then the following four tissues :-

I. The branchial epithelium.

2. The skeletal bars.

3. The connective tissue.

4. The blood cells; and also certain eosinophilous cells.

The Epithelium.-This varies in appearance in different parts, and requires further description. It has been figured and described most satisfactorily in the past by Janssens* and by De Bruynet, and we also show it in Figs. 4, 5, and IO, on Pl. I. A tract of the epithelium on each side of each filament bears especially long cilia, and these tracts are separated by a narrow non-ciliated zone from the front or free edge of the filament, which is covered by a uniform band of short cilia (Fig. 5). The depression between adjacent filaments, where they join, is never ciliated. The nuclei of all these epithelial cells are large and ellipsoidal (Fig. IO). The cells on the prominent free edge of the filament are of tall, columnar form; at the base and on the interfilamentar junctions they are cubical, squamous epithelium. Amongst these epithelial cells we find the large rounded granular cells, which were described by Lankester as secretion cells, by J. Chatin as "macroblasts," and by others as "Beckerzellen." They are clear and refracting in the white oyster, but distinctly green-coloured in the green oyster. They give a marked eosinophilous reaction (Fig. 5), and will be referred to again below in that connection.

The Skeletal Bars lie two in each gill filament, inside the epithelium and near the centre, in a section (see Fig. 5, etc.). They diverge outwards towards the outer edge of the filament, and either join or come into close proximity in the middle line of the free edge. They occasionally come in contact at their inner ends also (see Fig. 5). In the trough between two of the series of projections formed of filaments, the larger modified gill filament (the "segment primaire" of Janssens) has a pair of especially thickened skeletal bars of wedge-like shape, in section, and set at a wide angle to one another (Figs. 2 and 3). It is only these larger gill filaments, and usually only the alternate ones of these, that are continued into inter-lamellar junctions (Fig. 3).

The Connective Tissue forms a thin layer, in which the skeletal bars lie, inside the epithelium, and bounding the blood-channels in the branchial filaments and their junctions. It is a membrane nearly homogeneous or slightly fibrillated, with occasional fusiform or stellate connective-tissue cells, the nuclei of which are seen stained in the

* Les Branchies des Acephales. La Cellule, t. IX. fasc. I, p. 19 (1893). See also Kellogg, U.S. Fish Commission Bulletin, vol. X. (1892).

† Arch. de Biologie, t. XIV. (1895). 
sections. Here and there is found a large granular wandering cell, markedly eosinophilous, and precisely similar in character to those seen in the connective tissue of the mantle and those scattered through the epidermis of both mantle and branchix. These are to be regarded as granular leucocytes on their way to the exterior. They are shown in Figs. 9 and 13.

The Blood Cells are normally colourless leucocytes, measuring on the average Io $\mu$ in diameter (Fig. II). Some, however, are granular, and the granules may be yellow, brown, black, or green in colour. In diseased oysters, showing the green leucocytosis described below, the number of opaque granular leucocytes seems to become largely increased, and they are of a pale chalky-green colour. With osmic acid a black reaction is occasionally given by the granular leucocytes. In blood film preparations we have repeatedly tried to obtain evidence of an eosinophilous reaction in the normal leucocytes, but without success. On the other hand, the larger wandering cells in the tissues, or amœebocytes, are markedly eosinophilous.

Eosinophilous Cells.-Although we have not observed eosinophilous leucocytes in the blood-vessels, there are numerous cells in the tissues which give an eosinophilous reaction. Large ovoid cells are met with, scattered with some regularity along the free edge of the gill filaments (Pl. V., Fig. 3), and these, from the frequency of their occurrence, seem to be fixed elements of the epithelium ("Beckerzellen"). Corresponding cells in the mantle (Pl. V., Fig. 2) and intestinal epithelium have usually a pyriform appearance, and sometimes appear to be discharging their granular contents on the free surface. In the green American oysters described below, we have sometimes observed that these cells give a well-marked reaction with pure dilute hæmatoxylin (Pl. V., Fig. 8). There are also certain eosinophilous wandering cells which are found beneath the epithelium of the intestine, mantle, and branchix, and which, in some cases, are seen making their way through the epithelium to the exterior (Pl. V., Figs. 4 and 5); while other wandering cells-the green leucocytes of the American oyster-are never, in our experience, eosinophilous. The eosinophilous reaction, in fact, indicates merely a condition in which various epithelial and wandering cells may be found. 


\section{V.-THE PROTRACTOR PEDIS MUSCLE.}

\section{(See Plate II.)}

In opening large numbers of American oysters, usually a hundred at a time, we noticed the constant presence of a more or less distinct spot (P1. II., Fig. 2, sp.) on the mantle, near the anterior end of the visceral mass, and of a slight depression or mark on the shell over the spot (P1. II., Fig. I, sp.). The spot is circular, and about $2 \mathrm{~mm}$. in diameter; it is rather lighter and less opaque than the surrounding mantle, and its edges may be coloured with a deposit of dark brown or black pigment granules (see Pl. II., Fig. 3). At first we were inclined to think this the opening of a gland, or an aggregation of minute glands, as a watery fluid continued for some time after opening the oyster to ooze from the spot, and collect in a drop, which re-formed on removal. Dissection and the examination of sections showed, however, that we had to do with a band of muscular tissue, and that the "spot" was the insertion of the muscle, and the mark on the shell the scar produced by that insertion. This insertion mark has exactly the appearance and structure of the adductor impression. (Compare Figs. 4 and 5 with 6 and 7 , on Pl. II.).

This muscle has been noticed before. J. A. Ryder,* in 1884 and I893, writing of the mark on the shell, says: "It gives attachment to a feeble muscular bundle which springs out of the mantle on either side of the visceral mass, and when the animal is torn loose a slight whitish scar on the soft part marks its position on the surface of the mantle. I have been informed that Mr. W. H. Dall, who has investigated the matter, has identified this muscle with the pedal muscle of some other acephalous molluscs." R. T. Jackson, in his Phylogeny of Pelecypoda, $\dagger$ figures what is clearly our spot as a pedal muscle; but it is not mentioned by Kellogg in his work on the Morphology of Lamellibranchiate Mollusks. $\ddagger$

Huxley showed, in 1883 , that the first formed adductor muscle of the oyster, seen in the free-swimming larval stages, cannot from its position be the adductor present in the adult. The larval muscle, which is clearly an "anterior adductor" muscle, lies antero-dorsally in the body, and would require to traverse the alimentary canal to attain to the position of the adult muscle. Huxley predicted that a new second adductor muscle would be found to develop in the young oyster, and he argued, therefore, that oysters must be derived from dimyarian ancestors, and that their single large muscle is the persistent posterior adductor muscle, the anterior one being lost in early life. Jackson's discovery of a transitory dimyarian stage in the very young American oyster (Ostrea virginica, Gm.) proves the truth of Huxley's view.

* Contributions to the Life-History of the Oyster, I893, p. 719.

+ Memoirs Boston Soc. Nat. Hist., vol. IV., No. VIII., 1890.

+ Bulletin U.S. Fish Commission, vol. X. (1892). 
The idea that the small muscle passing inwards from the "spot"-which in position is a good deal anterior to the functional adductor-might be the reduced remains of the larval anterior adductor, is at once negatived by the observation that the fibres do not pass through the body from side to side, as adductor fibres must; but that we have to do with two distinct muscles, one on each side of the body. This, then, suggests the muscles for moving the "foot," and although there is no foot in the adult oyster, there can be no doubt that Ryder and Jackson were right in referring to this as a "pedal " muscle.

The muscles which may be present in other Lamellibranchs in relation to the foot are a protractor and an anterior and a posterior retractor on each side. The posterior retractor is out of the question. The protractor and the anterior retractor are usually inserted into the shell a little posterior to the anterior adductor muscle, and the protractor is the more ventrally placed of the two. The hinge line of the oyster is anterior, and if we may judge from Horst's figure of the larval oyster at the stage when the foot, as a ciliated ventral projection between the mouth and the anus, is in its most fully developed state, a protractor muscle would run posteriorly from in front of the mouth or œesophagus; while a retractor would, from what we know of it in other molluscs, probably be placed more dorsally, so as to cross the stomach. Our muscle runs antero-posteriorly, and is towards the ventral part of the visceral mass, close to the insertion of the labial palps. Such indications as we have, then, point to the "spot " being the place of insertion of the modified remains of the protractor pedis muscle.

The foot is however lost in the oyster at a very early period-while the larva is still free-swimming; and if the protractor muscle is present in the adult in this relatively large condition, it must be because it has become adapted to a new purpose. We have traced the muscle fibres in the American oyster by means of serial sections from the insertion into the shell (Pl. II., Figs. 9 and IO) at the "spot," posteriorly along the top or attached edge of the outer labial palp, to the anterior end of the branchial lamellæ. The fibres first run inwards, and then obliquely backwards (Fig. I I), and come into close relation with a large blood sinus (see Pl. II., Figs. I I, I2, I 3, lac), which lies in the mantle just over the attachment of the outer labial palp. The muscle then works its way round the sinus, so as to appear upon its ventral, and finally its inner face (Fig. I2). It thus comes to lie internal to some of the renal tubules, and close to the outermost cæca of the liver. Our muscle now crosses at right angles a bundle of muscle fibres running from the mantle downwards ventrally into the palp, and containing a large nerve, as is usual with the muscle bundles of the mantle. Finally, having reached the level of the posterior end of the palp, our muscle turns ventrally, and begins to spread out (Fig. 13) in the sub-epithelial tract of mesodermal tissue which lies between the top of the mantle lobe and the attachment of the gill lamellæ, and which is morphologically a part of the stem of the ctenidium. Most of the fibres end in the connective tissue, immediately under the epidermis, between the descending (internal) and the ascending (external) lamellæe of the outer gill. The whole course of the muscle is about $6 \mathrm{~mm}$. long in a moderately large oyster; it is about ${ }^{1} \cdot 5 \mathrm{~mm}$. in diameter where inserted into the shell, and less than half that size when it reaches the branchia. 
As to the probable function of this muscle in the existing oyster, its action clearly must be to draw the labial palps and the anterior end of the branchia forwards and outwards. When this action is imitated by means of forceps on the fresh oyster, the result is seen to be that the funnel leading to the mouth is widened and opened, and the "catchment area" by which the mouth is supplied becomes increased. We give a diagram, in Fig. I4, showing the relations of the protractor muscles of the two sides to the mouth and neighbouring parts, and we add in dotted lines the probable course of the muscles before the foot disappeared in ancestral oysters. It seems to us that when the muscle was no longer needed as a protractor pedis, it may readily have come to serve its present useful purpose by the posterior half of the muscle aborting, while the anterior half remained and acquired an attachment to the connective tissue of the palp and the gill through which it must have formerly passed, and where it is quite likely some of the fibres always ended.

Our figure (P1. II., Fig. I4), which, although drawn as a diagram, is true in its proportions, and was sketched directly from the living animal, shows clearly the configuration of the labial palps when the two protractor muscles are slightly drawn upon. The inner or posterior palps curl together in the middle line behind the mouth, while the outer or anterior palps diverge widely. The anterior ends of both gills on each side are received between the outer and inner palps of that side; so that the only avenue to the mouth, the passage on each side between the two palps, becomes much widened at its posterior end, more funnel-shaped, and evidently better adapted for collecting the food particles from the anterior ends of the gills, and passing them forward to the mouth.

The action of the oyster in opening its shell (i.e., divaricating the valves), preparatory to feeding, separates the points of attachment of the two muscles, and so of itself, even without any muscular contraction, causes the opening up of the food avenues described above: the contraction of the muscles which doubtless takes place will emphasize the same action.*

* The technical term "fishing" used by oyster-growers and others connected with the trade, to indicate the act of feeding in an oyster, is therefore so far a correct description, inasmuch as the action is comparable with the spreading of a net. 


\section{I. - L I V E R. \\ (See Plate III.)}

The large gastric gland commonly called "liver" in Mollusca is of course well known to be neither homologous nor strictly analogous with the liver of vertebrates. As the sole digestive gland acting upon all constituents of the food, it is more nearly analogous with the pancreas of higher animals, and has sometimes been called a hepato-pancreatic gland. We are, however, familiar in some of the higher invertebrates with glandular cæca of the mesenteron which act as stomach diverticula, and apparently receive, digest, and absorb a portion of the food. This may well be the case to some extent with the liver of the oyster. It may possibly have an absorbing as well as a secreting function to perform in connection with digestion, and it is highly probable that, in addition, it has important metabolic functions in connection with the elaboration and storing up of reserve materials, including pigments, from the food.

The liver communicates with the stomach by means of a wide passage on each side (Pl. III., Figs. 4 and 5), which almost at once divides (Fig. I3) into several branches or hepatic ducts leading to the cæcal lobules, which are lined by the hepatic cells. The ducts, as was pointed out by Ryder in I884, are lined by ciliated epithelium resembling that of the stomach (compare Figs. I4, I5, I6, \&c.), and so can always be easily distinguished in sections from the cæca, the walls of which are formed by the large irregular hepatic cells (Figs. 6, 7, 8, \&c.).

There is a considerable difference in the size of the liver and in the number of lobules or cæca in different oysters, and, moreover, the size of the cæca and of the hepatic cells seems to vary with the condition of nutrition of the animal, and also becomes reduced at the breeding time. One of the first points we noticed in connection with the green leucocytosis of certain American oysters, was, when examining the animals fresh, that they seemed to us to have the liver in a shrunken and degenerate condition. Carazzi objects to our use of this phrase, and seems to think that the liver is always in the same condition. Even a superficial examination of a large number of oysters, at different times and from different localities, is sufficient to show that he is mistaken, and that the "good conditioned" appearance of the oyster depends largely upon the state of the liver, as well as of the vesicular connective tissue around it. We now show by our figures the comparison between the healthy (Fig. IO) and the unhealthy (Fig. II) liver, the latter showing the condition which we meant to indicate by the terms "shrunken and degenerate" in our preliminary report.

The colour also of the liver varies greatly, and may be dark brown (Figs. I and 2), bright yellow brown (Fig. 3), or dull green. The liver cells stain readily with Ehrlich's hæmatoxylin, and with osmic acid granules can be demonstrated in abundance 
(Fig. 9). Barfurth and Frenzel have shown the presence of three kinds of cells in the glandular epithelium of the molluscan liver, viz._-"Körnerzellen," "Fermentzellen," and "Kalkzellen"; but not all of these are present in all cases. Frenzel* states in regard to the common oyster:- "(a) Die Körnerzellen haben einen Durchmesser von circa 32 mikr. Die Körner sind gelb- bis röthlich-braun gefärbt, 3 bis 4 milkr. gross und kugelig. Die granula sind wenig zahlreich und punktförmig. (b) Ferment- (Keulen-) Zellen nicht aufgefunden (März). (c) Kalkzellen fehlen.”

We find two kinds of glandular cells in the liver of our oysters-the ordinary large granular liver cells (Körnerzellen), and smaller, more deeply-staining cells, which we take to be Frenzel's "Fermentzellen." The relative positions, sizes, and appearance of these cells is shown in Figs. 6, 7, 8, \&c., on P1. III. We have in some cases (Fig. 12) observed the presence of small green pigment $f$ granules in the larger cells, but have not found any giving an iron reaction. Here and there, in the vesicular connective tissue between the cæca, may be seen (Fig. ro, e. chl.) the aggregations of dark green granules described as "entero-chlorophyll" by MacMunn. Whether this pigment is a modification of the yellow hepatochrome described by Miss Newbigin in the liver and integument of Crustacea, and which apparently may vary from red to green in colour, or is a derivative of chlorophyll from vegetable food, as held by MacMunn, and this seems very probable, cannot be determined without further investigation both spectroscopic and chemical. In the meantime, enterochrome (see Newbigin, Quart. Journ. Mic. Sci., November, 1898) certainly seems the more appropriate name for this pigment, or set of pigments.

* Mikrograplie der Mitteldarmdrüse (Leber) der Mollusken. Nova Acta Leop.-Carol. Akad., Bd. XLVIII., No. 2, 1886.

† Ryder also described green pigment in the inner ends of the liver cells in 1893 . 


\section{VII.-GREEN OYSTERS.}

\section{(See Plate IV.)}

The discovery of a green tinge of more or less intensity, which made its appearance on the mantle and other parts of the body of some of the oysters in our experiments, started us on a series of investigations into the minute structure of the green parts, and the nature and causes of greenness in general in oysters. One of the first conclusions we arrived at was that there are several distinct kinds of greenness in oysters, the confusion between which in the past has led to differences of opinion and unfortunate controversies. The colouration has been attributed to the most varied causes by different investigators. It has been localised in mantle, gills, palps, heart, liver, intestine, or any two, three, or all of these parts. It has been stated at various times to be due to copper, iron, chlorophyll, entero-chlorophyll, "bile-pigment," phycocyanine, and to the pigment of certain diatoms, and all these statements have again been contradicted. Probably each of them was more or less correct of the particular oysters or organs examined by their authors. It is unfortunate that some writers have given rise to considerable confusion and misapprehension by not confining their conclusions to the kind of oysters they investigated.

The green of our experimental oysters we saw at once was a very different matter from the rich blue-green of the healthy Marennes oyster; certain green Falmouth oysters are probably different from both; the Roach River green oysters are merely a paler variety of the Marennes greenness; and, again, there is a sickly grey-green tint seen in some Dutch oysters when they get into poor condition which is not exactly the same as any of the above.

Most of our work has been done on the pale green American oysters relaid on the Lancashire Coast; but we have also taken occasion to examine into the other varieties of greenness seen in the Marennes, the Roach River, the Falmouth, and the Dutch oysters. We have had Marennes and Dutch oysters sent to us direct from France and Holland, and one of us (W. A. H.) has visited all the chief oyster-culture stations on the French and Dutch Coasts.

I. Green Oysters of Marennes (P1. IV., Fig. I).-We agree with practically all previous investigators in regarding these oysters as being in a healthy conditionalthough green. Whether the green substance is derived from food taken in by the mouth, or from nutriment absorbed by the surface epithelium, there can be little doubt that it is a product of metabolism stored up in certain large granular cells met with in liver, intestine, and gills. It has been said to contain a small amount of iron, and is entirely different in its reactions from the copper-containing green pigment we have met with in some other oysters. With certain modifications, we accept Lankester's 
account of the greenness of the Marennes oysters as being correct. Carazzi, in his recent paper, makes a great point of the contents of Lankester's "secretion cells" ("Beckerzellen") of the branchix being always colourless, and he speaks of the error into which Lankester, Chatin, and others have fallen in considering these large globular cells to be sometimes loaded up with green granules. In this Carazzi is undoubtedly wrong. Although in ordinary colourless oysters the "secretion cells" are clear and colourless, in most green-gilled oysters (those of the Roach River in England, and some Dutch, as well as the Marennes) we find them to be distinctly green (P1. IV., Figs. 3, 4); and we are able to support Lankester in his views as to the origin of the colour, which Carazzi has attempted to demolish.

Carazzi says that an occasional green appearance in the secretion cells may be due to an optical illusion, the green of the neighbouring epithelium appearing by refraction to be in the large clear cell. We only mention this in order to state that we have provided against any such optical illusion. We have seen the green colour of the secretion cells quite distinctly, not only in surface views and in sections, but also in the isolated cells, in teased preparations of the living tissue. We have been able to show them in this condition to several of our colleagues, and all have agreed that the green colour, although of course faint in single cells, is quite distinct. Even when the neighbouring epithelium is slightly green, as it sometimes is, we are unable to admit that the large secretion cells do not contain green granules. We have not only isolated the cells, but in teased fresh preparations have isolated the large green granules; and after disorganizing these by pressure, have seen the green substance of the granules collecting again to form green globules. There can be no doubt from our preparations that the green colour is in the large granular cells.

Our experience of the Marennes oysters is that the green colouration is disposed as follows:-All over both surfaces of the four gills; on the ribbed or grooved adjacent (adoral) surfaces of the four labial palps-that is, on the posterior faces of the anterior, and the anterior faces of the posterior palps (the other sides of the palps are very faintly coloured, if at all); occasionally the œsophagus to some extent (this is not at all constant); more frequently the rectum (but sometimes a brown rectum is found in a green-gilled oyster); the loop of intestine that coils around the stomach; and, lastly, the liver, to some extent.

When a piece of the gill in the living state is put under the microscope, the large green "macroblasts" are clearly visible. They are often arranged in longitudinal rows-parallel to the long axis of the filaments-packed closely together (P1. IV., Fig. 3); sometimes they are a little spaced out, about their own diameter apart; in some places there are two rows on each filament in place of one, while in others they scem scattered quite irregularly. These cells give an eosinophilous reaction. In a previous paragraph (page 9) we have discussed the various forms of cosinophilous cells, and have shown that the regular grouping of these cells tends to indicate that 
they are epithelial cells ("Beckerzellen"); we also showed that certain other eosinophilous cells in the epithelium were clearly wandering leucocytes, and of the same nature as the wandering cells met with in the connective tissue.

C. de Bruyne, ${ }^{*}$ in his recent extensive work on Phagocytosis in Lamellibranchs, shows that in these molluscs there is a considerable exodus of leucocytes on the surface of all epithelia, both mucous and tegumentary. He considers that the diapedesis of leucocytes is always very important in the branchial epithelium, and becomes increased in the presence of any irritation. Our experiments described further on (p. 20) show that this- is certainly the case in the oyster.

We regard the wandering cells with green granules, whether eosinophilous or not, which we find so plentifully in the epithelium of the gills and mantle (see Fig. 3), as leucocytes which are on their way to the surface, and as being of the same nature as the wandering cells we meet with in the connective tissue.

2. Roach River Green Oysters. - Certain parts of the estuaries of the Roach and the Crouch, in Essex, have long been known to produce green oysters; but these are usually regarded with so much suspicion in this country that, although healthy and delicately flavoured, they have to be sent abroad to find a market. We give a figure (Pl. IV., Fig. 9) of one of these oysters, $†$ showing the rather pale blue-green colour of the gill. We find nothing abnormal or unhealthy in these oysters, and no unusual amount of copper or other metal in the green parts. The structure of the branchiæ and the cause of their colour are apparently the same as in the case of the Marennes oyster.

On the Essex coast, just as in the case of the French "claires," the Oystergrowers notice that immediately before the oysters become green, in autumn, a large amount of fine grcen weed or "moss" makes its appearance in the estuaries in question. We are indebted to Mr. E. Newman, manager of the Colne Oyster Company, for obtaining samples of this so-called "moss" for us to examine. We are now able to state that this green layer which appears as a coating on the mud ("London clay"), is a matted mass of minute Algæ, almost wholly Cyanophyceæ, such as Microcoleus chthonoplastes, Lyngbya majuscula, and L. semiplena. This is very similar, then, to the "verdure" of the French "claires" we have examined, except that in the latter several species of Cladophora were also abundant. (See Herdman "On Oyster Culture on the West Coast of France," Trans. Biol. Soc. Liverpool, vol. VIII., p. II3). In both cases many Diatoms are present, and these, along with the blue-green Cyanophycer, must form an important part of the oyster's food.

3. Green Dutch Oysters. - A large number of Dutch oysters from Nieuport, in Belgium, were sent over to us in January and February, I897, by Dr. J. L. C. Pompe van Meerdervoort, who complained of a diffused greenness which appeared in October

* Contribution à l'Etude de la Phagocytose, Arch. de Biol. t. XIV., 1895; also t. XV., p. 270, I898.

†From a batch kindly procured for us by Messrs. Cooke Bros., Oyster Merchants, West Mersea. 
all over the bodies of his oysters, kept in artificial tanks, and which culminated in December in a more marked greening of the gills and labial palps, at the same time that the oysters became thin, watery, and transparent.

Our friend Dr. P. P. C. Hoek, of Helder, who happened to be working in our laboratory soon afterwards, examined these green oysters with us; and he has since written to us about a diffused greenness (which we find to be the same as that from Nieuport) which has broken out among the oysters stored on the farms at Bergen-opZoom, on the East Scheldt. Dr. Bottemanne, Inspector of Fisheries at Zeeland, has kindly sent us specimens of these green oysters from the Scheldt, and we find them to be, like those sent from Nieuport by Dr. Pompe van Meerdervoort, very thin oysters, in poor condition, with emaciated livers. Fig. 6 on Pl. IV. shows one of the largest of these Dutch oysters, and illustrates the characteristic colour of gill; but in most cases associated with this green colour we find a much smaller body, a shrunken liver, and a transparent watery mantle. Evidently mal-nutrition is one cause of the diffused pale greenness of these Dutch oysters. The reason of the mal-nutrition in these localities must be studied by some one on the spot; but it very probably lies in the practice of keeping the oysters in artificial cement tanks, into which water is only occasionally admitted. Even although the sea-water contains the usual amount of food, still Diatoms and other minute forms of life cannot be so abundant on the cement of the tank as they are on the mud forming the bottoms of estuaries, "claires," and pits.

Figs. 7 and 8 show, under a high power, sections of the external surface of the mantle, where (Fig. 7) a certain amount of green pigmentation of the epithelial cells is seen, in addition to several large coarsely-granular eosinophilous cells. There are also (Fig. 8), in the connective tissue under the epithelium, groups of large green globules, which are evidently MacMunn's “entero-chlorophyll." Fig. I0, showing a transverse section of the intestine unstained, is of considerable interest, as it shows that the green colour of the alimentary tract of this variety is due to a pigment in the epithelial cells. Thus the green colouration of this oyster is not similar to that found in the American oysters. Nor do we consider that it is identical with the green of the Marennes oyster, as the pigment is here (as our figures show) more generally diffused through the epithelium, and not aggregated in "macroblasts." The distribution and general appearance of these minute pigment granules recalls that of the green granules in the intestinal epithelium of Chetopterus, as described and figured by Ray Lankester ; ${ }^{*}$ but the two pigments are quite distinct in their nature. It is evident, from recent work by Professor Lankester, Miss Newbigin, and others, that entirely distinct animal pigments may seem histologically very much alike in position and appearance. $\dagger$

4. Falmouth Green Oysters.-From time to time in the past, since I7I3, when a case of poisoning at the Hague + was attributed to oysters unlawfully coloured with

* Quart. Jour. Micros. Sci., vol. XL., p. 447.

† See Miss Newbigin's recent Paper in Quart. Jour. Micros. Sci., Nov. I899.

$¥$ See O'Shaughnessy-Ann. and Mag. Nat. Hist., vol. XVIII., 1866. 
copper to simulate the natural tint, green oysters from Falmouth and clsewhere in Cornwall have been suspected or accused of containing copper, derived from old mines or metalliferous strata in the sea. Quite recently Dr. Thorpe* has found on the average about 0.023 grains of copper oxide per oyster (in some cases much more) in specimens from Falmouth and Truro. On relaying, the green Cornish oyster gradually loses its colour, and is then found to contain only about 0.0062 grains of copper per oyster, which is practically the normal amount ( 0.4 milligramme) which we find in white "native" oysters from Whitstable.

Dr. Thorpet says, "There is no question that the greenness of certain oysters, especially of those found in Falmouth and Truro waters, is due to copper. The colour, both in character and distribution is, however, quite different from that of the Marennes oyster." We can corroborate this. It is in effect what we have been stating for the last three years in our preliminary reports-that there are several kinds of green oysters; the "Huitre de Marennes" is one of them, the copper-containing green oyster is another.

In the Falmouth oyster, containing an excessive amount of copper, we find that much of the copper is certainly mechanically attached to the surface of the body, and is in a form insoluble in water-probably as a basic carbonate. In addition to this, however, the Falmouth oyster may contain a much larger amount of copper in its tissues than does the normal colourless oyster. In these Falmouth oysters the cause of the green colour appears to be the same as in the green American oysters. Some of them also show (see Pl. VI., Fig. 8) a green heart of exactly the same nature as that of the green American oysters (Pl. VI., Figs. 3, 7, 8).

5. Green American 0ysters. - This is the oyster at which we have chiefly worked. It is brought to Liverpool in large quantities, and is laid down on various parts of the neighbouring coast to be fattened and to be stored till required for the market. For some years it has been noticed that certain of these re-laid Americans may become grcen in the Autumn, the greenness being entirely different from that of the Marennes and other oysters we have examined, and consisting in a large increase of the granular green leucocytes of the blood in the heart, and in the sinuses and the tissues of the mantle, and also on the surface of the mantle, but very rarely in the gills. The result of this leucocytosis is that a more or less vivid green colouration is produced, which may be almost anywhere on the surface of the body, although it is most frequently over the liver, and the visceral (anterior) part of the body (see Pl. VI., Figs. 3-7, and 9). It may occur in patches or streaks, or very usually it is confined to the heart and blood channels, which are then engorged with a pale chalky-green mass of the granular leucocytes; in some cases, owing to the universal injection of the vessels and smaller blood spaces, the entire oyster has a greenish tinge (Fig. 6).

The oysters in which this massing of the green leucocytes occurs do not appear

* Local Govt. Bd. Report on Oyster Culture in relation to Disense, p. 105.

† Nalure for Dec. 3rd, 1896, p. 107. 
to us as healthy as those which are colourless. They are frequently thin, with the liver shrunken, but we were unable to find evidence of any parasite or other irritative cause of the disease, either by staining or by cultivation. On the other hand, it is evident from experiment that an irritation of the surface of the mantle will determine the presence of leucocytes at the point. We have shown this by trephining the shell, and by removing pieces of shell to form "windows," which we closed by paraffined water-tight corks. We have also carefully removed one valve without causing any hemorrhage, and have kept the oysters, which were healthy yellow Americans, alive for more than a week. On the first day green leucocytes began to appear on the mantle. On the second day they were more abundant, especially on and around the adductor muscle and over the heart. This condition increased for about two days more, and then began to disappear. The leucocytes causing the green spots were granular and actively amœboid.

At an early period of the investigation we were inclined to agree with some previous investigators that copper, though present in small quantity (on the average 0.006 grains) in all oysters, had nothing to do with this green colour; but last year we definitely announced* that we had found copper in considerable quantity (up to four times the normal amount) in these green American oysters, and that the copper reaction coincided histologically with the green granular leucocytes, and that consequently the copper may fairly be regarded as the cause of the green colour.

In the next section we give an account of our chemical analyses of the copper and the iron present in these and other oysters; and in the succeeding section on the micro-chemistry we show the evidence upon which we base our statement that the superabundant copper of these oysters is contained in the granular green leucocytes. 


\section{VIII.-IRON AND COPPER IN OYSTERS.}

Dr. Charles A. Kohn has kindly made for us, from time to time, chemical analyses of oysters from various localities, and in different conditions of colouring; in the following account we quote freely from his notes, and the reports* he has given us, and from our conversations with him on the results of the experiments.

The early observations of Dumas (184I) and of Berthelot (1855), which showed that the green colour of French oysters ("Huitres de Marennes") is not due to chlorophyll, and not to copper, though possibly to iron, have been recently extended by A. Chatin and A. Muntz $\dagger$ From their analytical results these observers conclude that both the green and the brown colourations of the various types of French oysters are due to the presence of iron, and that the depth of colour bears a close proportion to the quantity of iron contained. The colourations are chiefly apparent in the gills, but extend also to the labial palps and parts of the alimentary canal. Chatin and Muntz base their conclusions, in the first place, upon the fact that they find considerably more iron in the gills than in the rest of the body of green oysters, and secondly, upon the occurrence of a larger quantity of iron in the gills of green than of white oysters.

The cause and origin of this colouration is a physiological problem of much interest, but the confirmation or refutation of Chatin and Muntz' results also appeared of importance in connexion with the investigations on Oysters and Disease, and therefore the following experiments on the occurrences of copper as well as of iron in various kinds of oysters were undertaken. The point at issue is not so much the nature of the colouring matter, nor whether it does or does not contain a small quantity of iron, but simply whether the coloured parts of the green oysters contain proportionately such an excess of the metal that the colour can be attributed to its presence. This has not been found to be the case. The determination of the copper appeared to be of some interest, since poisonous effects have often been attributed to its presence, although earlier observers have shown that a small quantity is a normal constituent of the blood of the oyster.

Electrolytic methods of analysis were adopted both for the determination of iron and copper; these methods Dr. Kohn has already shown (Brit. Assoc. Reports, I893, p. 726) possess marked advantages for the estimation of minute quantities of metal, 
especially if derived from organic matter, for they are quite free from any prejudicial influences traces of organic matter may exert, such as arise when volumetric or colorimetric methods are employed. In each determination the bodies or gills only of six or more oysters were carefully washed, dried between filter paper to remove as much adherent moisture as possible, and then carefully dried in porcelain dishes in the airbath at $100^{\circ} \mathrm{C}$. When this drying was as complete as possible, the oysters were heated in the air-bath until thoroughly carbonized, the carbon carefully burnt off over the free flame, and the residue finally ignited in a porcelain crucible. Special care was taken to exclude dust during both the drying and the ignition. The ash was then thoroughly extracted with a mixture of 25 c.c. hydrochloric acid and 25 c.c. sulphuric acid $(1: 2)$ on the water-bath, and the resulting solution filtered and concentrated. The residue was free from both copper and iron. The acid solution obtained was electrolysed for copper with the usual precautions, a spiral of fine platinum wire, weighing about 5 grms., being employed as the cathode. The wire was determined in iron. the residual solution, after neutralization with ammonium hydrate, \&c., acidifying with a few drops of oxalic acid solution, and boiling with ammonium oxalate. Four grme. of the oxalate were added in each case, the precipitated calcium oxalate (which is quite free from iron) filtered off and thoroughly washed, and the resulting solution electrolysed, the metallic iron being also deposited on a spiral of platinum wire. A blank experiment with all the reagents employed was made, and the amount of metal found ( $0.0002 \mathrm{grm}$. iron) deducted in each case. Also the deposited metal, both iron and copper, was dissolved off the electrode by acid, the solution obtained tested by the ordinary reagents, and the spiral re-weighed as a check upon the determinations, since the quantities found were extremely small.

\section{I.-Determination of the Iron.}

The following table* gives the results obtained, the quantities of iron found in green French as compared with white American oysters, three sets of gills being analyzed in each case. The figures show conclusively that there is more and not less iron in the gills of the white American oysters than in the French, and this irrespective of the basis on which the result is calculated. The ash is undoubtedly the most reliable factor to calculate on, provided the oysters are carefully washed before drying, which is always done : the result per set of gills (or oyster) is most in accord with this, and has the advantage of being an easy and in many respects useful basis.

* We are indebted for all the Tables in this section to the careful work of our colleague at Liverpool, Dr. C, A, Kohn, and we take this opportunity of thanking him nost cordially for his kindness in helping us. 


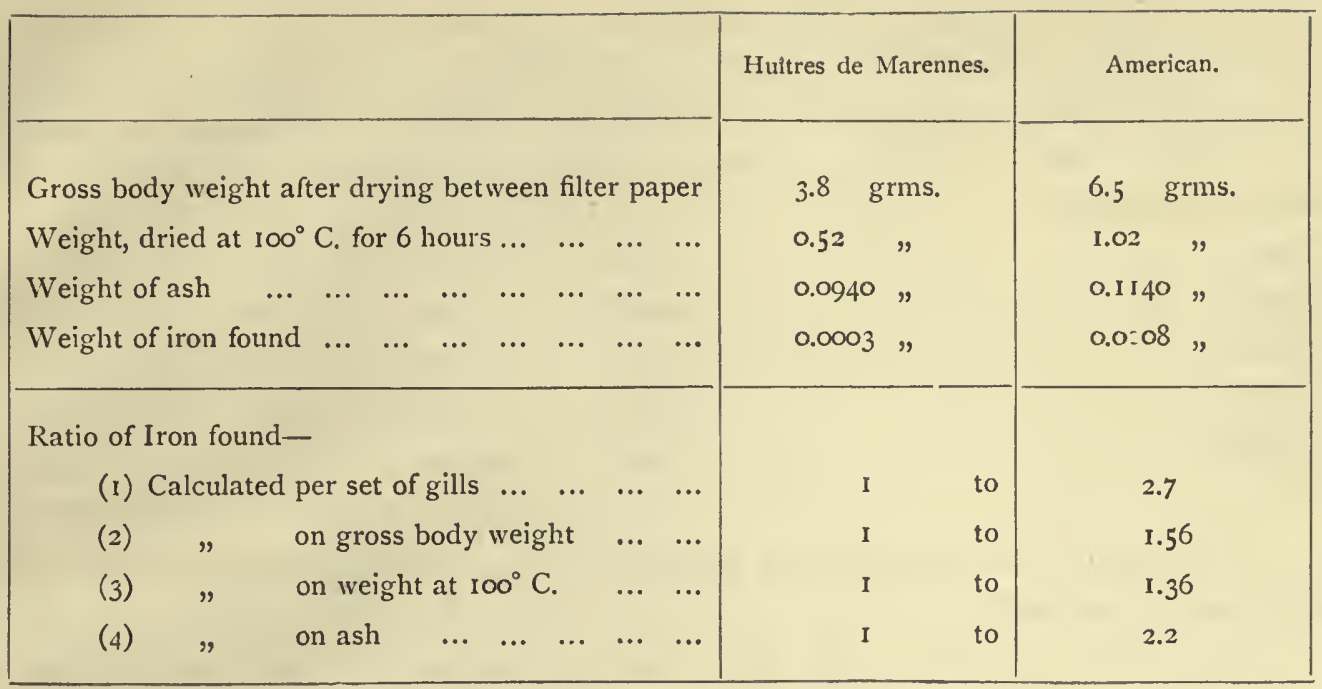

The relative quantities of iron present in the gills as compared with the rest of the body were next determined in French, Dutch, and American oysters. Six oysters, or the gills of six oysters, were analyzed in each case with the following results :-

\begin{tabular}{|c|c|c|c|}
\hline \multirow{2}{*}{ Six Oysters. } & \multicolumn{3}{|c|}{ Weight of Iron found, in Mgrme. } \\
\hline & French. & Dutch. & American. \\
\hline $\begin{array}{lllllllll}\text { Gills } & \ldots & \ldots & \ldots & \ldots & \ldots & \ldots & \ldots & \ldots\end{array}$ & 0.6 & 0.4 & 2.3 \\
\hline $\begin{array}{lllll}\text { Bodies minus gills } \ldots & \ldots & \ldots & \ldots & \ldots\end{array}$ & 1.2 & 1.5 & 1.7 \\
\hline Weight of ash of gills ... & 0.1880 & 0.0217 & 0.0294 \\
\hline$" \quad \quad \quad$ of bodies minus gills ... & 0.5980 & 0.1125 & 0.1240 \\
\hline$\%$ iron in ash - gills $\quad \ldots \quad \ldots \quad \ldots$ & 0.32 & 1.85 & 7.82 \\
\hline$"$-bodies minus gills & 0.20 & 1.33 & 1.37 \\
\hline $\begin{array}{l}\text { Ratio of Iron in gills to Iron in rest } \\
\text { body- }\end{array}$ & & & \\
\hline Calculated per oyster & I : 2 & $I: 3.75$ & I : 0.74 \\
\hline $\begin{array}{lllll}\text { on } \operatorname{ash} & \ldots & \ldots & \ldots & \ldots\end{array}$ & $1.6: \mathrm{I}$ & I : $4 . \mathrm{I}$ & $5.7: 1$ \\
\hline
\end{tabular}

Finally, the total iron in a number of kinds of oysters was determined in order to ascertain the normal quantity present. These data, which are tabulated below, show a fairly constant proportion of iron per oyster, from 0.15 to 0.36 mgrme., or from 0.18 to 0.65 per cent. on the ash. 
Total Iron present in Oysters.

\begin{tabular}{|c|c|c|c|c|c|}
\hline Kind of Oyster. & $\begin{array}{l}\text { Number } \\
\text { Analyzed. }\end{array}$ & $\begin{array}{c}\text { Total Iron. } \\
\text { Grme. }\end{array}$ & $\begin{array}{l}\text { Weight of } \\
\text { Ash. }\end{array}$ & $\begin{array}{l}\text { Mgrme. Iron } \\
\text { per Oyster. }\end{array}$ & $\begin{array}{l}\text { Percentage } \\
\text { Iron on Ash. }\end{array}$ \\
\hline Huîtres de Marennes... ... & 6 & 0.0018 & 0.7860 & 0.30 & 0.23 \\
\hline $\begin{array}{llllll}\text { Dutch } & \ldots & \ldots & \ldots & \ldots & \ldots\end{array}$ & 6 & 0.0009 & 0.1393 & 0.15 & 0.65 \\
\hline $\begin{array}{lllll}\text { American } & \ldots & \ldots & \ldots & \ldots\end{array}$ & 5 & 0.0018 & 0.2791 & 0.36 & 0.64 \\
\hline $\begin{array}{llllll}\text { Colne } & \ldots & \ldots & \ldots & \ldots & \ldots\end{array}$ & IO & 0.0020 & 1.0938 & 0.20 & 0.18 \\
\hline $\begin{array}{lllll}\text { Deep Sea } & \ldots & \ldots & \ldots & \ldots\end{array}$ & 2 & o co64 & I. 5017 & 0.32 & 0.43 \\
\hline $\begin{array}{lllll}\text { Falmouth } & \ldots & \ldots & \ldots & \ldots\end{array}$ & 6 & 0.0016 & 0.4534 & 0.27 & 0.35 \\
\hline
\end{tabular}

In considering the variations in quantity, the very small amounts of metal present must be borne in mind.

From these figures in the above tables it is evident that there is not an excessive quantity of iron in the gills of the green oysters-the proportion of iron in the gills as compared with the rest of the body is somewhat more ( $1: 2$ ) than that found in Dutch oysters ( 1 : 3.7 ), but much less than in American oysters, which are white (I.4: I). The comparison is purposely made on the absolute quantity of metal in the gills and the rest of the body, as any other basis for calculation is fallacious.

Chatin and Muntz reckon on the weight of the dried organic matter present but it was not found possible to get anything approaching constant weights in this way. This may to some extent account for the difference in our results, but we should also like to point out that although the ratio of iron in the gills and the rest of the body in green and in brown oysters is from I : $\mathrm{I} .8$ (feebly green) up to I : 2.3 (very green), they also instance white oysters with a proportion of $\mathrm{I}:$ I.6.

It is certainly somewhat strange that they find more iron in the gills than in the rest of the body in all cases, which is not the case in our own experiments. But the quantities of metal present are so small that, since they do not state how many oysters were taken for analysis, and employ the permanganate method for the estimation of the iron, it is difficult to say what degree of absolute accuracy their results represent, and therefore to judge in how far their analytical data justify their conclusions.

From two points of view the above results show that the greenness of the gills of French oysters is certainly not due to iron:-

(I) Because the gills of the green oyster contain less iron than the rest of the body.

(2) Because the proportion of iron in the gills as compared with the rest of the body in white (American) oysters is greater than in the green.

That our method is reliable is shown by two determinations of the iron in the gills of American oysters, one giving 2.3 and the other 1.8 mgrme. of iron per six sets of gills. Variations in the size of the oysters will of course account for small differences, especially with the bodies. 
It is evident from the last table that both the gills and the rest of the body of oysters contain normally (as would naturally be expected) a small quantity of iron, the gills having a somewhat larger amount in proportion to the total quantity of mineral matter present, but quite irrespective of the colour of the gills.

\section{II.-Determination OF THe Copper.}

Harless and Bibra* first showed that phosphate of copper was present in the blood of Molluscs (Cephalopoda), and Fredericq subsequently extended the observation $\dagger$ and proved that a certain small amount of copper is found normally in the blood of various Shellfish (both Crustaceans and Molluscs). It is apparently in combination with a proteid, to which Fredericg gave the name "hémocyanine."

The quantity thus present in oysters of different origin is fairly constant, as shown in the following table : it varies from 0.25 to 0.66 mgrme. per oyster, or from 0.30 to I.1 8 per cent. on the ash :-

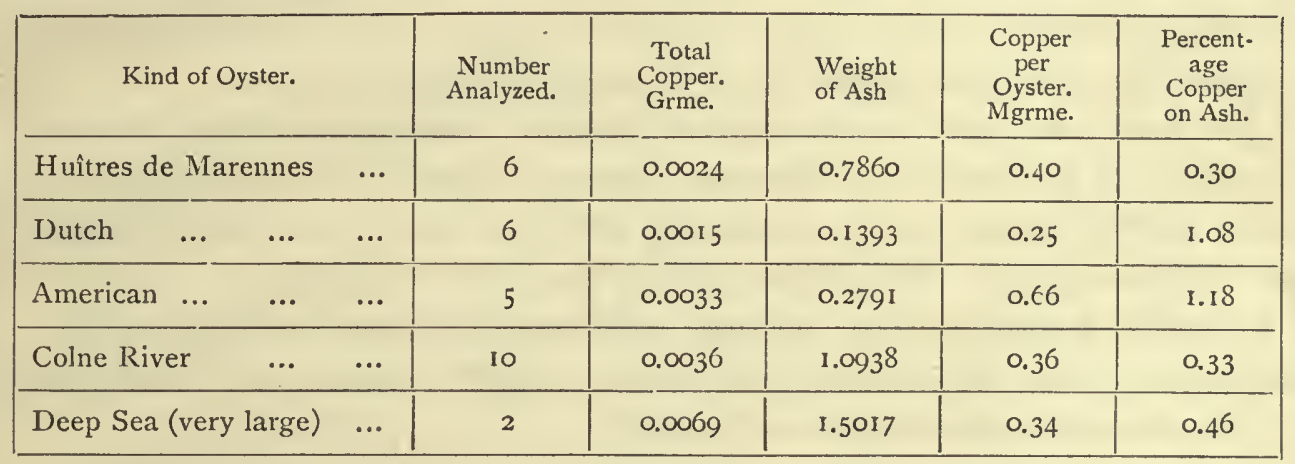

For copper, then, 0.4 mgrme. per oyster may be taken as an average, a quantity slightly greater than the average iron ( 0.26 mgrme.). The calculated percentages on the ash show greater variations, due to the very considerable differences in the total quantities of mineral salts present; and it is very possibly to this last factor that the well-known differences in taste of the various kinds of oysters is at any rate in part due. Certainly the minute quantities of copper and iron present cannot account for the flavour, as has been sometimes suggested.

The copper was also determined in the gills, and in the bodies minus gills, of French, Dutch, and American oysters, with the following results :-

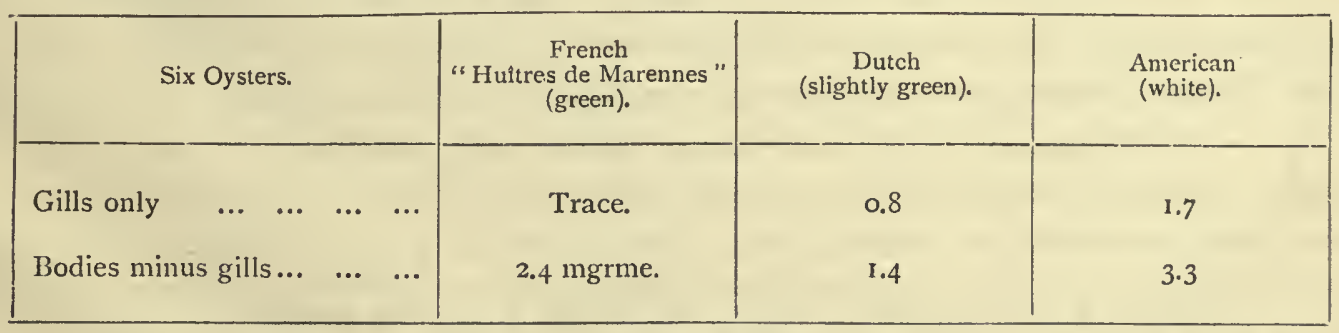


These results show that copper is present normally in both green and in white oysters in small quantity, but that the greenness of the gills of French oysters is certainly not due to this metal-in fact they contain only the merest trace.

Experiments which we have made on the feeding of oysters with very dilute saline solutions of iron and of copper salts, entirely confirm these analytical data. Beyond a certain amount of post-mortem green staining, the oysters did not acquire any green colour. We give the details of these feeding experiments further on.

There are, however, some green oysters (not the "Huitres de Marennes") which, as we have already stated, contain much more copper than those analyzed above. They are probably under abnormal conditions. Such cases are certain Falmouth oysters, and the American oysters with the green leucocytosis.

Dr. Thorpe has shown that some green oysters picked out by Dr. Bulstrode at Falmouth and Truro contained as much as 0.02 grains per oyster on the averagesome contained much more; while we find that the green American oyster from Fleetwood, where the greenness is due to the leucocytes, has on the average 0.0229 grains of copper per oyster-between three and four times the normal amount.

We have been able to obtain some of these green oysters from Falmouth for examination and analysis. Six Falmouth oysters ( $O$. edulis), the bodies of two of which were of a distinct arsenic green colour, were dried at $100^{\circ} \mathrm{C}$. and then digested with water, and subsequently with dilute hydrochloric acid. The extract contained about half the total copper present, showing that the metal is partially, at any rate, mechanically retained in or on the body of the oyster,* probably as a basic carbonate.

The analytical results were as follows:-

\begin{tabular}{|c|c|c|c|c|c|c|c|}
\hline Six Oysters. & Copper. & Iron. & $\begin{array}{c}\text { Weight } \\
\text { of } \\
\text { Ash. }\end{array}$ & $\begin{array}{l}\text { Mgrme. } \\
\text { Copper } \\
\text { per } \\
\text { Oyster. }\end{array}$ & $\begin{array}{l}\text { Mgrme. } \\
\text { Iron per } \\
\text { Oyster. }\end{array}$ & $\begin{array}{l}\text { Per eent. } \\
\text { Copper } \\
\text { on Ash. }\end{array}$ & $\begin{array}{l}\text { Per cent. } \\
\text { Iron } \\
\text { on Ash. }\end{array}$ \\
\hline Extract with dilute acid & 0.0097 & 0.0024 & 0.2272 & 1.62 & 0.40 & 4.22 & 1.06 \\
\hline Oysters & 0.0114 & 0.0016 & 0.4534 & 1.90 & 0.27 & $2.5 \mathrm{I}$ & 0.35 \\
\hline Total ... & 0.0211 & 0.0040 & 0.6806 & 3.52 & 0.67 & 3.10 & 0.59 \\
\hline
\end{tabular}

The total copper present here is almost nine times the normal quantity, and about half of this is easily removed by dilute acid. It is quite likely that the remainder of the excess is partially or wholly simply entangled in the food passages of the oyster.

The occurrence of copper in oysters, under such conditions, in some parts of Cornwall is due to the locality, and might quite possibly attain injurious proportions. The oysters analyzed were obtained from a creek which is locally supposed to bring

*Dr. Thorpe, in a letter to Nature (1896, p. 107), referring to the large proportion of copper in these Falmouth oysters, speaks of it as "obviously caused by the mechanical retention of cupriferous particles." 
down copper from old mines, and the mud of which was found by Thorpe to contain O.I48 per cent. of copper. Normal sea-water contains such an excessively small quantity of copper that it was not found possible by Dr. Kohn to detect its presence, even electrolytically, in a litre of sea-water, after concentration.

Taking, finally, the green leucocytosis found in some American oysters, the six greenest and six whitest of 120 of these oysters, as re-laid on our coast, were chosen for analysis; also a quantity of the greenest portions of the greenest oysters was selected from another batch, and compared with the corresponding portions of the whitest oysters. The iron was not determined in the latter comparison, owing to the possible contamination by that metal in the cutting.

The following were the results obtained :-

\begin{tabular}{|cll|c|c|c|c|c|c|c|}
\hline \multicolumn{2}{|c|}{ Oysters. } & & Copper. & Iron. & Ash. & $\begin{array}{c}\text { Mgrme. } \\
\text { Copper } \\
\text { per } \\
\text { Oyster. }\end{array}$ & $\begin{array}{c}\text { Mgrme. } \\
\text { Iron per } \\
\text { Oyster. }\end{array}$ & $\begin{array}{c}\text { Per ent. } \\
\text { Copper } \\
\text { on Ash. }\end{array}$ & $\begin{array}{c}\text { Per cent. } \\
\text { Iron } \\
\text { on Ash. }\end{array}$ \\
\hline & & & & & & & & & \\
Green ... & $\ldots$ & $\ldots$ & 0.0158 & 0.0091 & 1.1450 & 2.63 & 1.52 & 1.38 & 0.79 \\
White ... & $\ldots$ & $\ldots$ & 0.0042 & 0.0036 & 1.0948 & 0.70 & 0.60 & 0.38 & 0.33 \\
Greenest parts & $\ldots$ & 0.0033 & - & 0.0780 & - & - & 4.23 & - \\
Whitest parts & $\ldots$ & 0.0009 & - & 0.0452 & - & - & 1.99 & - \\
\hline
\end{tabular}

The excessive quantity of copper in the selected green oysters is 3.75 times that in the white ones, calculated per oyster, and 3.63 times calculated on the ash. In the selected parts the total copper present calculated on the ash is high in both cases, and the green parts again show a marked excess in the proportion of 2.I to I. The copper and iron in the white specimens are about normal, but the increased quantity of iron in the green is marked, being 2.5 times that of the former. Still there is relatively a large excess of copper as compared with iron in the green oysters, as is evident from the analyses, the ratio being I.I : I for the white, and I.8 : I for the green.

It is to be concluded, therefore, that the green colour of these diseased American oysters is coincident with the distribution of the excessive quantity of copper present, and that the copper is in consequence to be regarded as the cause of the colour. The histo-chemical investigations given further on confirm this conclusion.

Manganese was also found by Dr. Kohn to be present in several of the kinds of oysters analyzed. Its detection is readily effected in the electrolytic method of analysis, as it separates at the anode as peroxide. Colne oysters contain 0.14 mgrme. per oyster, a quantity rather smaller than the amount of iron present.

We must now turn to Dr. D. Carazzi's recent papers, in which he tries to show that the green colouration in oysters is in all cases a healthy condition, caused by the absorption of iron as a nutrient material from the surrounding medium by means of the surface epithelial cells, such as those of the branchix and palps. A good deal that is 
stated by Carazzi is quite correct, but these are points which wcre known before. The novel statements are, we believe, entirely erroneous, and are the results either of mistaken observations, or inferences from observations.

He rightly states that the Marennes green oysters may retain their colour for weeks or even months when taken to other waters in which greening does not take place. It is true of our green Marennes oysters, kept for weeks practically without food in tanks in the laboratory. This fact is well known, and has been mentioned by various writers from Bouchon-Brandely, in $187 \mathrm{I}$, onwards; but does it not tell strongly against Carazzi's own view that the green substance is a nutrient material on its way from the surface epithelium to the liver? Is it at all likely that; if the green "Marennin" is a nutrient material in process of metabolism, it will remain for months in the superficial tissue (which by Carazzi's hypothesis has just absorbed it) after the source of supply has been removed? That is very improbable, even admitting Carazzi's statement as to the distribution of the iron-containing Marennin in the superficial cells to be correct; but we do not admit it. As we have shown above, we have abundant evidence that the green granules are constantly in the "macroblasts," and comparatively rarely in the ciliated epithelium. In fact, in all essential points of structure-the details of which need not be gone over again-we agree with Lankester, Pelseneer, J. Chatin, and De Bruyne, and differ from Carazzi in his criticism of these former authors.

Moreover, all the observations made by ourselves, and those recorded by others, on the West Coast of France are in accord with the view that the "greening" depends upon microscopic food-organisms in the sea-water. Bornet and Ad. Chatin showed, in 1894, that the greening comes on suddenly in parks at Sables d'Olonne, where it was not present before. The greening, again, only takes place at a certain time of year, usually autumn, which agrees with the periodic distribution of minute organisms. Bouchon-Brandely says that at Marennes it is a common observation that the oysters only become green when the water in the "claires" (ponds) has become green with microscopic plants. It is known at La Tremblade that when a claire is in the greening condition it must not be emptied, as a change of the water might deprive it of its greening properties. Moreover, the greening must be due to the contents of the water, since in the Island of Cuhan (La Trinité River) Dr. Gressy has successfully reared green oysters in basins excavated in the solid rock.

We must call attention to the way in which Carazzi has peremptorily denied* or misrepresented the results of some of the many investigators of molluscan anatomy and physiology with whom he does not agree. For example, he says of Ryder's statement that the ventricular part of the heart may be green, "he is certainly mistaken," \&c. We are able, however, to state that Ryder was perfectly correct, and that it is

* It is perhaps sufficient, as an example of Carazzi's style, to state that after alluding to the work of Lankester, Pelseneer, and others, he makes the sweeping assertion:- "Tutto quel ch' è stato detto finora sulle ostriche verdi è completamente sbagliato, ed è la conseguenza di osservazioni n infondate o malamente interpretate." 
Carazzi who is mistaken, as we have found exactly the condition that Ryder describes in American oysters (see Pl. VI., Fig. 7).

In connection with this we may state that we have had the advantage of discussing very fully the iron and copper reactions, and Carazzi's statements and criticisms, with Professor A. B. Macallum, of Toronto, recently in our laboratory. Macallum, who is the author of the hæmatoxylin method of demonstrating iron in tissue-cells, agrees with us entirely, and wishes to repudiate Carazzi's remarks in regard to the iron reaction

Finding that we considered it necessary to take notice of Carazzi's papers, Dr. Macallum has asked us to insert the following note, which he had already written out for publication, as a statement of the method in which Carazzi has misinterpreted and misapplied his (Macallum's) and Zaleski's reactions :-

"In his reference to the literature Carazzi has, in some cases, been particularly inexact. He attributes to Macallum a method of liberating the organic iron of cellular elements (treatment with Bunge's fluid), in order to demonstrate it in the usual way, which that observer not only did not use, but also expressly describes as unsuitable for the purpose. Carazzi obtained negative results only with this method, the only one which he used, and yet he ventures on the basis of results so obtained to deny the correctness of Macallum's observations. In regard to Zaleski, Carazzi is almost equally inaccurate. Zaleski states specially that if the isolated liver-cells are extracted with physiological salt solution, and the residue subjected to artificial digestion after thorough peptonization, nucleins remain in which the iron can be shown 'nicht aber mehr durch die unmittelbare Anwendung der Eisenreagentien,' but after complete incineration only. One nuclein compound, not obtained in this way, did indeed give an immediate reaction for iron; but Carazzi practically states that all the iron-holding nucleins isolated by Zaleski reacted immediately for iron, and then claims that this accounts for all the iron found in the nucleus by Macallum. An inexact knowledge of the litcrature on a subject is bad, but a criticism based on it is worse-it is mischievous." 


\section{IX.-MICRO-CHEMISTRY OF THE GREEN OYSTERS.}

\section{(See Plates VII. and VIII.)}

The following are the details of the histo-chemical investigation of the pigment of the green American oysters with the leucocytosis. The green pigment is insoluble in boiling alcohol, ether, chloroform, xylol, and other fat solvents; it is soluble in dilute acids and alkalies. The addition of potassic ferrocyanide to sections containing the green colouring matter, or to the leucocytes themselves, gives a red reaction, indicating the presence of copper; but the reaction can be most readily obtained by the addition of a small quantity of 5 per cent. hydrochloric acid to the potassic ferrocyanide. Ammonium hydrogen sulphide gives also an immediate reaction with the green pigment. Ammonia strikes a beautiful blue wherever there is green in marked quantity. It was also found that pure hæmatoxylin is an extremely delicate test, giving an immediate blue reaction in exceedingly dilute solution. Previous treatment of the green colouring matter by 3 per cent. nitric acid in alcohol prevented these reactions, and subsequent treatment with acidulated potassic ferrocyanide resulted in a very faint Prussian blue colouration of the tissue generally (marking out especially the nuclear zone in any epithelium present). We concluded that there was no organic iron present in the leucocytes, that the leucocytes which form the green patches contain a considerable quantity of copper, and that, just as in the case of iron, as shown by Professor Macallum, pure hæmatoxylin is a most delicate test for copper, but that great care must be taken to ascertain by other reagents which of the two metals is present.

Very numerous tests were made with the blood obtained from white oysters, and micro-chemical reactions revealed in some instances faint traces of copper. Hæmocyanin has been described in the blood of various Molluscs, and apparently in the blood of the oyster. We have examined numerous samples of blood taken from the white oyster, but have failed to get any blue colouration on exposure to air. In the green oysters a very faint blue colour has been noticed in some cases on exposing the blood to air.

To demonstrate the presence of copper in the green leucocytes collected in the vessels, the tissues may be examined fresh or after hardening.

Fresh Blood.-By means of a fine pipette the green corpuscles are removed from the heart or other blood space they have collected in, and placed on a cover slip and allowed to dry. The dried film, which has a green tint, is then treated with the clear dilute hæmatoxylin solution, and at once assumes a deep violet colour. Similarly, with 
potassic ferrocyanide, after previous immersion in very dilute acid, a distinct reddish colouration is obtained, visible to the naked eye. Fig. 3 on Pl. VII. shows part of such a preparation under the microscope. Colourless corpuscles obtained from oysters which are not green do not give these reactions. The best preparations of the copper-containing leucocytes are obtained by treating freshly-teased vessels, or sections of vessels, after imbedding in paraffin, with the various reagents (see Pl. VII., Figs. I, and 4-9). The leucocytes in bulk then give well-marked reactions; in many of the cells the reactions can be plainly seen, the granules in them assuming a reddish tint in the case of potassic ferrocyanide, or violet with hæmatoxylin."

Vessels and Heart.-In well-marked cases of leucocytosis the green heart (Pl. VII., Fig. 2, b) may be removed from the oyster, treated first with dilute acid, and then with potassic ferrocyanide, when a brown colouration is readily obtained; the organ may then be dehydrated, passed through oil of cloves, and mounted in Canada balsam. Similarly the vessels may be stripped off from the mantle and treated as above-such specimens are seen in Figs. I and 4. The most instructive preparations are, however, obtained by first hardening the green oysters. Figs. 5-9 on Pl. VII., and Figs. 5 and 6 on P1. VIII, show a series of sections through the body of the oyster, and passing through one of the larger pallial sinuses close to the mantle edge, which in this case was engorged with green leucocytes. One section, Fig. 7 , has been treated with potassic ferrocyanide; Fig. 9 has been stained with the colourless solution of hæmatoxylin; Fig. 8 has been treated with ammonium hydrogen sulphide; and Fig. 6 is an untreated section which plainly shows the green colour. Similar reactions are demonstrated in our series of sections (which it seems unnecessary to reproduce, as they show the same colours as Figs. 6-9) passing through the auricles and ventricle; the conjoined auricles, it will be observed, have normally a dark brown colouration, and do not give any change, the ventricle containing the leucocytes only reacting.

Under high magnification (see Pl. VIII.) the best pictures* are yielded by the hæmatoxylin-treated sections. Wherever there are copper-containing leucocytes, these stain immediately with the reagent, and by their colour stand out in marked contrast with the surrounding colourless tissue. This is well illustrated in Pl. VIII., Figs. I to 4. In many of the sections we found that the large eosinophilous cells in the mantle of the green oysters gave a strong reaction with hæmatoxylin; this was the case in the oyster from which P1. V., Fig. 8, was made. That eosinophilous cells should give such a reaction is remarkable, and is to be explained by the fact that in some cases these cells contain copper.

* In these and the other figures illustrating the micro-chemical reactions, we have given the colour effects, distribution of granules, and shades, but have not represented the further histological details which these methods were not intended to demonstrate. 


\section{X.-EXPERIMENTS IN FEEDING WITH METALLIC SALTS.}

With the object of trying to produce in the laboratory results similar to those observed in Nature, and with the view of testing the part which the absorption of metallic salts might play in colouring the oyster, and in possibly rendering it unfit for human food, we have made, during the last couple of years, a large number of experiments by keeping oysters in tanks in which definite quantities of various salts of iron and copper had been added to the sea-water.*

In all cases we first of all ascertained that our oysters, both Americans and Natives, were healthy and colourless, so far as we could judge by observing them through the opening between the shells when in the expanded condition. We could make sure at any rate that the mantle and the gills were not green, and we always opened a few specimens of the same batch as a control.

In the first place, we tried the effect of pieces of copper, copper filings, and copper dust lying in the bottom of the aquarium; and similarly, of steel filings, old rusty nails, and other fragments of iron. We also kept oysters for some time in an old copper vessel, and along with copper pyrites and other ores of copper. None of these gave any definite result.

We then, with Dr. Kolnn's assistance, tried measured quantities and strengths of various metallic salts. On Feb. 5th, I896, we added 0.2 per cent. of sulphate of copper to Io litres of sea-water in which a few oysters were placed; while another set of oysters had the same quantity of ferric ammonium citrate added to their ro litres of water. From these we got no definite results. The oysters lived better in the iron water than in the copper. The only staining was a deposition on the shell and in the mucus of the mantle edge, and some post-mortem colouration in the case of those that died.

On Feb. 27th we started three colourless American oysters in each of three aquaria containing insoluble salts, viz., sulphide of iron, ferric hydrate, and copper oxide, in each case 50 grains being added to one gallon of sea-water. By March 5th, those in the copper oxide fluid were evidently sickly, while the others seemed healthy. On March I2th, those in the copper oxide no longer reacted under stimulation, and were evidently just dead. On being opened, they had all the appearance of ordinary yellow oysters, the gills and palps were normal, and there was no trace of staining in any part. On March 2Ist, one from each of the other aquaria was opened. They were

* Recently Carazzi has stated that oysters fed with similar dilute iron solutions acquire a pale yellowish colour in certain parts (branchial epithelium and the œesophageal mucous membrane), and that in these parts microscopic tests show the presence of granules of iron. The actual meaning of these results can harclly be recognised without comparative and quantitative data. 
found to be alive and healthy, with the heart beating actively, and no green or brown staining in any part. The rest were opened on March $26 \mathrm{th}$, and found to be in the same healthy condition.

Dr. Kohn then made us up some soluble salts, and on May 27th two batches of oysters were put in tanks of sea-water containing a small amount of chloride of copper. On June 4th, three were found to be dead, and on examining these one had a slight greenish tinge over the viscera and a green spot in its heart, and the second had a good deal of green over the right side of its mantle, and many of its vessels were engorged with pale green leucocytes. The third specimen was not green, and in none of them was there any greenness in the gills. Twenty of these same oysters, opened at the beginning of the experiment, showed only one slightly green specimen. On June 5th, another specimen from the copper solution showed a greenish mantle, and the following day the remaining five oysters, when opened, were found to be all more or less tinged with green-as follows :-

$A$. Green on mantle over viscera, and slightly on mantle over gills. Heart very green and chalky.

$B$. Green on mantle over gills, and heart slightly so.

$C$. Green on mantle over gills, and heart very green.

$D$. Very green on mantle over gills, and slightly over viscera. Heart pea-green.

E. Slightly green on mantle over gills and over viscera. Heart pale chalky green.

The gills themselves were scarcely affected in any case. In the case of the mantle, the staining was not on the surface, but in the leucocytes in the tissues and blood spaces.

A second batch started on June 5th, in the same soluble copper salt, were opened on June IIth and I2th, when it was found that all had their hearts more or less green, and the mantle over the viscera stained, and having blood-vessels engorged with green leucocytes. Most of them had the mantle over the gilis stained of a greyish-blue colour. The gills themselves were not affected in any case. A control batch of four of the same oysters kept in ordinary sea-water showed, however, one heart very green and the other three slightly so. One had the vessels over the viscera engorged, and there was a little green staining in the mantle of all.

It was evident, then, that these oysters were becoming green to some extent, quite apart from any action of the copper, but those in the copper solution were decidedly greener than the control oysters. On June I 2 th, some further experimental batches were started, $(A)$ in ordinary sea-water, $(B)$ in a solution of the same copper salt in which Io c.c. was added to the gallon, and $(C)$ another in which I c.c. was added per gallon. On June 18th, $(A)$ showed four normal oysters, and one specimen a little green in the heart; $(B)$ showed one specimen normal, and four all somewhat green; $(C)$ showed three with no green, two with engorged vessels containing green leucocytes, and one of them with a green heart. 
These are samples of a large number of similar experiments* made with different salts of copper and iron, soluble and insoluble, and of various degrees of strength, which give, on the whole, the following results :-

I. In no case was any greening at all comparable with that of the Marennes oysters produced.

2. The insoluble salts which lay as a deposit at the bottom of the aquarium seemed to produce little, if any, effect.

3. The soluble salts of iron either produced no effect, or had a favourable effect, the oysters living rather.better in these solutions than in ordinary sea-water. They gave rise to no greening.

4. The very weak soluble copper-salts had little, if any, effect; while the stronger copper-salts had always an unfavourable effect upon the life of the oyster, causing death sooner or later; and in most cases producing more or less of that unhealthy green leucocytosis which we had found in various kinds of oysters bedded around our "coast, and which Ryder evidently found amongst oysters on the American coast.

* Since this was written we have carried out (October to December, 1898) a series of further experiments at the Lancashire Sea Fisheries Hatchery at Piel Island, in the Barrow Channel. The oysters were kept in tanks through which a constant current of fresh sea-water was running. To this current measured quantities of dilute copper and iron salts were added drop by drop, in such a way as to mix thoroughly with the sea-water before reaching the oysters. We have examined these oysters, and find that those that have been for from one to three weeks in the current containing the copper solution, show evidence of having more than the normal amount of copper in their bodies, but still there was no apparent greening. Those in the iron solution were unaffected.

These experiments are being continued for us by Mr. Andrew Scott, Resident Assistant at the Piel Hatchery, and will be shortly extended to mussels and cockles, which, we find, are also liable to become green. 


\section{XI.-ON THE CONNECTION BETWEEN OYSTERS AND}

\section{INFECTION.}

From the earliest times more or less well grounded suspicion has been cast from time to time upon shellfish-chiefly Oysters and Mussels-as being the cause of outbreaks of disease amongst consumers, such as:-Ist. Cases of sudden poisoning due to the presence of putrefactive products in the shellfish; and 2nd. Diseases due to a specific micro-organism, where there is a period of incubation, and where therefore a considerable interval has elapsed between the infection and the actual illness. In the latter case it is obviously much more difficult to determine with certainty the source from which the disease germ has entered the body; and although many positive assertions have appeared of late years attributing outbreaks of enteric or typhoid fever to the consumption of oysters, still it must be pointed out that the connection between the two, although quite likely, has not yet been scientifically proved, and is only at present more or less of a possibility, or, at most, probability.

During the past three years we have been making a number of observations and experiments, both in our Liverpool laboratories and at the Port Erin Biological Station, upon the conditions under which oysters live healthily, and upon the possibility, or even in some cases the probability, of their being the carriers of disease germs. During that period much public interest and apprehension has been raised by several recent outbreaks of typhoid popularly attributed to oysters, such as that of the Stirling Ball in October, I895; that of the Wesleyan University in Connecticut, investigated by Professor H. W. Conn in I894; and that in the south of France attributed to Cette oysters, reported upon by Dr. Chantemesse in 1896 . It was obvious from these, and from numerous other outbreaks of typhoid attributed to eating oysters, that the conditions under which the shellfish were liable to become contaminated with sewage, and so be the carriers of pathogenic organisms, required investigation. The following is a brief account of our experiments and observations.

A. The objects we had in view in entering on the investigation were as follows :-

I. To determine the conditions of life and health and growth of the oyster by keeping samples in sea-waters of different composition; e.g., it is a matter of discussion amongst practical ostreiculturists as to what specific gravity or salinity of water, and what amount of lime, are best for the due proportionate growth of both shell and body.

2. To determine the effect of feeding oysters on various substances-both natural food, such as diatoms, and artificial food, such as oatmeal. Here, again, there is a want of agreement at present as to the benefit or otherwise of feeding oysters in captivity. 
3. To determine the effect of adding various impurities to the water in which the oysters are grown, and especially the effect of sewage in various quantities. It is known that oysters have been sometimes grown or laid down for fattening purposes in water which is more or less contaminated by sewage, but it is still an open question as to the resulting effect upon the oyster.

4. To determine whether oysters not infected with a pathogenic organism, but grown under insanitary conditions, have a deleterious effect when used as food by other animals.

5. To determine the effect upon the oyster of infection with typhoid, both naturally, i.e., by feeding with sewage water containing typhoid infection, and artificially, i.e., by feeding on cultures of the typhoid organism.

6. To determine the fate of the typhoid bacillus in the oyster-whether it is confined to the alimentary canal, and whether it increases in any special part or gives rise to diseased conditions; how long it remains in the alimentary canal; whether it remains and grows in the pallial cavity, on the surface of the mantle and branchial folds; and whether it produces any altered condition of these parts that can be recognised by the eye on opening the oyster.

7. To determine whether an oyster can free its alimentary canal and pallial cavity from the typhoid organism when placed in a stream of clean sea-water; and if so, how long would be required, under average conditions, to render infected oysters practically harmless.

B. The methods which we employed in attaining these objects were as follows :-

I. Observations upon oysters laid down in the sea at Port Erin :-

(a) Sunk in 5 fathoms in the bay, in pure water.

(b) Deposited in shore pools, but in clean water.

(c) Laid down in three different spots in more or less close proximity to the main drain-pipe opening into the sea below low-water mark.

These observations were to ascertain differences of fattening, condition, mortality, and the acquisition of deleterious properties as the result of sewage contamination.

II. Observations upon oysters subjected to various abnormal conditions in the nlaboratory.*

(a) A series of oysters placed in sea-water and allowed to stagnate, in order to determine the effect of non-aëration.

(b) Similar series in water kept periodically aërated.

(c) A series placed in sea-water to which a measured quantity of fresh (tap) water was added daily, to determine the effect of a reduction of salinity.

* The oysters were kept in basins, in cool rooms of constant temperature, shaded from the sun, both at the Port Erin Biological Station, and also in the Pathological and Zoological Laboratories at University Coliege, Liverpool. 
(d) A series of oysters weighed approximately, and fed upon the following substances, viz:-(I) Oatmeal, (2) Flour, (3) Sugar, (4) Broth, (5) Living Protophyta (Diatoms, Desmids, Algæ), (6) Living Protozoa (Infusoria, \&c.), (7) Earth.

In this series of experiments the oysters were fed every morning, and the water was aërated but not changed (evaporation was compensated for by the addition of a little tap water as required). The oysters were weighed from time to time, and observations made upon the apparently harmful or beneficial effects of the above methods of treatment.

(e) A series of oysters placed in sea-water to which was added daily :-

(I) Healthy frcal matter.

(2) Typhoid frecal matter.

(3) Pure cultivations of the typhoid bacillus.

The oysters were carefully examined to determine their condition, with special reference to condition of branchix, alimentary canal, adductor muscle, liver, and viscera generally.

The contents of the rectum, as well as the water in the pallial cavity, were subjected to bacteriological analysis, to determine the number of micro-organisms present, per cubic cm., as well as the identity of the typhoid or other pathogenic organisms.

C. The following is a summary of the results obtained :-

I. The beneficial effects of aëration :-

(a) By the addition of air only,

(b) By change of water :

pointing to the conclusion that the laying down of oysters in localities where there is a good change of water, by tidal current or otherwise, should be beneficial.

II. The diverse results obtained by feeding upon various substances, amongst which the following may be noted:-The exceedingly harmful action of sugar, which caused the oysters to decrease in weight and then die; whilst the other substances detailed above enabled them to maintain their weight or increase. The oysters thrive best upon the living protophyta and protozoa. Those fed upon oatmeal and flour after a time sickened, and eventually died. Some were fed upon quantities of a minute green alga (Microcystis), which we happen to have in abundance in a fountain. This did not result in any greening of any part of the oyster.

III. The deleterious effect of stagnation, owing to the collection of excretory products, growth of micro-organisms, and formation of scum upon the surface of the water.

IV. The toleration of sewage, \&c. It was found that oysters could, up to a certain point, render sewage-contaminated water clear, and that they could live for a prolonged period in water rendered completely opaque by the addition of frecal matter ; that the fæcal matter obtained from cases of typhoid was more inimical than that 
obtained from healthy subjects; and that there was considerable toleration to peptonized broth.

V. The infection of the oyster by micro-organisms.

The results of the bacteriological examination of the pallial cavity of the oyster, and of the contents of the rectum, showed that in the case of those laid down in the open water of the Bay the colonies present were especially small in number, whilst in those laid down in proximity to the drain-pipe the number was enormous (e.g., I7,000, in one typical culture, as against Io in the former case). It was found that more organisms were present in the pallial cavity than in the rectum. In the case of the oysters grown in water infected with the Bacillus typhosus, it was found that there was no apparent increase of the organisms, but that they could still be identified in cultures taken from the water of the pallial cavity and rectum fourteen days after infection.

It was found that the typhoid bacillus would not flourish in clean sea-water, and our experiments seemed to show that it decreased in numbers in its passage along the alimentary canal of the oyster. It would seem probable, therefore, that by methods similar to those employed in the "Bassins de dégorgement" of the French ostreiculturists, where the oysters are carefully subjected to a natural process of cleansing, oysters previously contaminated with sewage could be freed of pathogenic organisms or their products without spoiling the oyster for the market.

It need scarcely be pointed out that if it becomes possible thus to cleanse infected or suspected oysters by a simple mode of treatment which will render them innocuous, a great boon will have been conferred upon both the oyster trade and the oyster-consuming public.

The remaining sections of this memoir deal with further points and investigations in connection with the infection and disinfection of the oyster and other shellfish. 


\section{XII.-CONDITION OF OYSTER BEDS AND LAYINGS.}

It has been known for some time that many of the places in estuaries or harbours where oysters are laid down to fatten, or to await their market, have been kept in a most insanitary condition, either because the water as a whole is polluted, or because the opening of some drain-pipe is in such close proximity that the discharge from the drain is liable to pass over the shellfish. We showed in 1895 , in our preliminary paper, that oysters have a very remarkable power of withstanding organic impurities in the water, and can continue to live in water much polluted with sewage. In fact they are able, if kept sufficiently aërated, to render water almost opaque with sewage clear in a wonderfully short time.

As the result of our observations on oyster-beds, and our experiments on the kinds of water in which oysters will live, we recommended, in January, 1896,*

"Ist, A strict examination of all grounds upon which oysters are grown or bedded so as to ensure their freedom from sewage; and

2nd, If practicable, the use of 'dégorgeoirs' or disgorging tanks, in which the oysters should be placed for a short time before they are sent to the consumer."

Towards the end of the same year, the Local Government Board Report on Oyster culture in relation to Disease, containing sections by Sir Richard T. Thorne, Dr. H. T. Bulstrode, and Professor E. Klein, appeared, giving detailed statements as to the insanitary conditions under which oysters are grown or kept on various parts of our coasts. Dr. Bulstrode has shown conclusively, by his descriptions and plans, what was known previously only to those who had taken the trouble to look into the matter, that while some of the localities from which our oysters come to market are excellently suited for the purpose and free from reproach, other "layings" are in a disgraceful condition of sewage contamination. That is undoubted; but as to the further question, whether the typhoid organism, if it gains access to the body of the oyster from sewage, finds itself in a suitable medium for continued life and multiplication, it is difficult to arrive at any definite conclusion. Professor Klein's experiments, like our own (see below, p. 45), are not sufficiently extended to be positive upon this point. There is, however, a marked difference between the cultures obtained from oysters taken from a contaminated source and those from pure water free from all possible sewage pollution. The body of the oyster is probably not a favourable medium for the growth of pathogenic organisms, the risk of infection is probably therefore never great, and if a little more care were exercised there would be practically no danger at all.

\footnotetext{
* Report to the Lancashire Sea Fisheries Committee: Trans. Biol. Soc. Liverpool. Vol. X., p. 174.
} 
What is really required is-

Ist. That some central, or local, Authority should inspect and license the oyster beds and layings, and that without such license, no oysters should be sold*; and

2nd. That all those who cultivate and those who sell oysters should exercise ordinary common sense, and elementary notions of decent cleanliness, in their responsible position as purveyors of an important and nutritious article of diet.

Mr. C. E. Fryer, in the recently published 12 th Annual Report of the Sea Fisheries Inspectors for England and Wales, discusses this question, and points out the difficulties in the way of preventing polluted oysters being shipped from unlicensed to licensed beds, and in regulating the importation of foreign oysters. However, as he himself states, these difficulties are not insurmountable.

We quite agree with Mr. Fryer's further remark, that whatever precautions and regulations are adopted for preventing the distribution of contaminated shellfish, they ought to include measures for duly apportioning among the various parties concerned (such as those interested in the drains as well as those interested in the oysters) the responsibility for the contamination.

* Since the above was written, an Oyster Bill has been laid before Parliament, which, although capable of improvement in some details, does much to meet the present difficulties. 


\section{XIII.-THE BACTERIOLOGY OF THE OYSTER AND OTHER SHELLFISH.}

Our investigations under this head have been made in the following directions:-

I. The Identification and Differentiation of the Bacillus typhosus and B. coli communis.

2. The action of sea-water upon the growth of the Bacillus typhosus.

3. The infection of the oyster with the Bacillus typhosus.

4. The bacteria present in the alimentary canal of the oyster and other shellfish.

5. The occurrence of Bacillus enteritidis sporogenes in shellfish.

In September, I896, an abstract of our results was published at the Liverpool Meeting of the British Association, and shortly afterwards the Local Government. Board Report upon "Oyster Culture in Relation to Disease" appeared (November, I896). The report was a very full one, and was furnished by Dr. Bulstrode and Professor Klein, and summarised by Sir Richard Thorne Thorne. The ground covered by Professor Klein and by ourselves was much the same, and our results approximated to his. Since then we have continued the work, and have repeated and extended our observations, of which the following are the more important.

I.--The Identification and Differentiation of Bacillus typhosus and B. COLi COMmunis.

We have systematically tested the majority of the chief differential reactions upon samples of $B$. typhosus and $B$. coli obtained from numerous sources, and have in all cases found unmistakable differences between the two bacilli. 
Table showing Differences of Reaction.

\begin{tabular}{|c|c|c|c|c|c|c|c|}
\hline \multicolumn{4}{|c|}{ Source. } & $\begin{array}{l}\text { Fermentation, } \\
\text { Glucose } \\
\text { Gelatine. }\end{array}$ & $\begin{array}{l}\text { Indol } \\
\text { Reaction. }\end{array}$ & Coagulation. & $\begin{array}{l}\text { Potassiun } \\
\text { Iodide } \\
\text { Potato } \\
\text { Gelatine. }\end{array}$ \\
\hline \multicolumn{4}{|c|}{ I. -B. typhosus. } & & & & \\
\hline \multicolumn{2}{|r|}{ I Institut Pasteur } & $\ldots$ & $\therefore$ & None. & None. & None. & $\begin{array}{l}\text { Very small } \\
\text { growth. }\end{array}$ \\
\hline \multicolumn{4}{|c|}{2 From spleen of Typhoid patient } & $"$ & $"$ & $"$ & $"$ \\
\hline \multirow{2}{*}{\multicolumn{4}{|c|}{$\begin{array}{llll}3 & \text { Prof. Delépine ... } & \ldots & \ldots \\
4 & \text { Prof. Wright }(\text { Netley)... } & \ldots\end{array}$}} & $"$ & $"$ &, & ", \\
\hline & & & & $"$ & Slight trace. & $\begin{array}{l}\text { Clot slowly } \\
\text { formed. }\end{array}$ & $"$ \\
\hline 5 & $\ldots$ & ... & ... & $"$ & None. & None. & $"$ \\
\hline 6 & Dr. Sims Wood & iead & ... & $"$ & $"$ & $"$ & $"$ \\
\hline 7 & $\cdots \quad \cdots$ & $\cdots$ & $\cdots$ & ", & $"$ & $"$ & $"$ \\
\hline \multirow{2}{*}{$\begin{array}{l}8 \\
9\end{array}$} & $\ldots \quad \ldots$ & $\ldots$ & ... & " & $"$ & $"$ & $"$ \\
\hline & $\int$ Dr. Kanthack & $\cdots$ & $\ldots$ & $"$ & " & $"$ & $"$ \\
\hline \multicolumn{4}{|c|}{$\begin{array}{c}\text { Io Institute of Preventive } \\
\text { Medicine } \ldots\end{array}$} & $"$ & $"$ & $"$ & $"$ \\
\hline \multicolumn{2}{|r|}{ I Institut Pasteur } & ... & $\cdots$ & Well marked. & Marked pink. & Marked. & $\begin{array}{l}\text { Growth } \\
\text { abundant. }\end{array}$ \\
\hline \multicolumn{2}{|r|}{2 Prof. Delépine ... } & ... & ... & $"$ & Slight pink. & $\cdot \quad$, & $"$ \\
\hline \multicolumn{2}{|r|}{3 Prof. Wright $\quad \ldots$} & ... & ... & $"$ & Pink. & $"$ & $"$ \\
\hline \multicolumn{2}{|r|}{$\begin{array}{llll}4 & 1 & \ldots & \ldots\end{array}$} & $\ldots$ & ... & $"$ & Slight pink. & $"$ & $"$ \\
\hline 5 & $\ldots$ & $\cdots$ & $\cdots$ & $"$ & Marked pink. & $"$ & $"$ \\
\hline \multirow[t]{2}{*}{6} & $\cdots \quad \ldots$ & $\ldots$ & $\cdots$ & $"$ & Pink. & $"$ & " \\
\hline & Dr. Sims Woor & lead & $\cdots$ & $"$ & $"$ & , & $"$ \\
\hline 8 & $\cdots$ & $\cdots$ & $\cdots$ & $"$ & $"$ & $"$ & $"$ \\
\hline 9 & $\cdots$ & $\cdots$ & $\cdots$ & $"$ & " & $"$ & $"$ \\
\hline \multirow{2}{*}{$\begin{array}{l}10 \\
11\end{array}$} & $\cdots$ & $\cdots$ & $\cdots$. & $"$ & $"$ & $"$ & $"$ \\
\hline & $\begin{array}{lll}\gamma & \ldots & \ldots\end{array}$ & $\cdots$ & $\cdots$ & $"$ & $"$ & $"$ & $"$ \\
\hline \multirow{2}{*}{$\begin{array}{l}12 \\
13\end{array}$} & Dr. Kanthack ... & $\cdots$ & $\cdots$ & $"$ & Slight pink. & $"$ & $"$ \\
\hline & $\ldots \quad \ldots$ & $\cdots$ & ... & $"$ & Absent. & $"$ & $"$ \\
\hline \multicolumn{4}{|c|}{14 Institute of Preventive } & $"$ & $"$ & $"$ & $"$ \\
\hline
\end{tabular}

Summary of Constancy or Variability of Reactions.

B. typhosus.-(I) Fermentation test; no gas formation. (2) Indol reaction; slight indication in one case. (3) Milk coagulation; slight clot in one case. (4) Potassic iodide potato gelatine; characteristic invariably. (5) Potato; constant with usual precautions. (6) Reaction in gelatine; marked differences of rate of diffusion. 
B. coli.-(I) Fermentation; rate of gas formation variable. (2) Indol reaction; not constant. (3) Milk coagulation; constant. (4) Potassic iodide potato gelatine ; abundant growth. (5) Behaviour in gelatine; diffusion very variable, in many cases less rapid than with $B$. typhosus. (6) Motility; very variable.

This preliminary investigation proved of great service in familiarizing ourselves with the appearances of typhoid and colon bacilli, and prepared the way for the subsequent investigations.

\section{II.-The Action of Sea-Water upon the Growth of the B. Typhosus.}

Eight experiments were made to ascertain whether the $B$. typhosus was capable of multiplying in sea-water. The subject was naturally one of very considerable importance in connection with the liability of oysters to infection when grown in sewagecontaminated water. Our experiments showed that sea-water was inimical to the growth of the B. typhosus.

When a large number of bacilli are added to the water, their presence may be demonstrated longer than in cases where smaller quantities are used. Fourteen days would appear to be the average duration in sea-water incubated at $35^{\circ} \mathrm{C}$.; whilst, kept in the cold, their presence was demonstrated, as will be seen by experiment VII., on the twenty-first day. There appears to be no initial or subsequent multiplication of the bacilli. Between forty and seventy hours after infection there is less decrease than at other periods; but there is no evidence of increase in numbers of the bacilli, when grown in sea-water, either when incubated or at ordinary temperatures. Dr. Klein, in his Report, states that in no instance did he find evidence of multiplication of the bacilli in the sea-water. He was able to recover the bacillus up to the fourth week. In I889, Giaxa made a series of observations upon the vitality of the $B$. typhosus in sterilized and non-sterilized sea-water, and showed that it was present in the latter up to the ninth day, and in the former to the twenty-fifth. In this connection may be taken the observation of Frankland and Ward,* that a 3 per cent. salt solution most prejudicially influences the growth of the $B$. typhosus, the latter disappearing by the eighteenth day. Experiments similarly conducted upon the propagation of the B. typhosus in fresh water have yielded similar results. Thus Kraus showed that a very rapid decline of the bacillus, and a very rapid increase of the ordinary sea-water bacteria, took place when the water was incubated. Frankland and Ward showed that the bacillus disappeared at the end of thirty-four days in unsterilized Thames water, and that there was no multiplication in potable water.

How far all these laboratory experiments may be taken as indicating what actually takes place in nature, it would be difficult to say. The bacillus probably does perish in a short time in the sea, just as it does in sea-water in the laboratory, but 
we have no evidence before us to show how far this is so in the case of the mud upon which the oysters may be laid; here it is possible that the bacillus might be capable of a saprophytic existence. The observations of Loesener, Robertson, and others concerning the duration of vitality of the $B$. typhosus in artificially infected earth, would tend to support such a view.

Tables showing the Action of Sea-water upon the Growth of the B. typhosus.

\section{EXPERIMENT I.}

At time of mixing After 2 I hours $\begin{array}{rrrrr}" & 45 & , & \ldots & \\ " & 7 \text { I } & , & & \ldots \\ " & 95 & , & \ldots & \\ , & 27 \text { I } & , & & . \\ & 340 & , & \ldots & \end{array}$

EXPERIMENT II.

At time of mixing ... After 2I hours...

$\begin{array}{rrr}" & 45, \\ , & 71, \\ , & 95, \\ & 271,\end{array}$

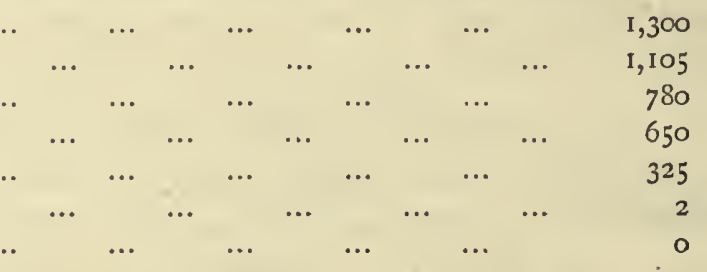

EXPERIMENT III.

At time of mixing After 5 hours

$\begin{array}{rrrr}" & 23 & , & \ldots \\ " & 48 & , & \\ " & 72 & , & \ldots \\ " & 247 & , & \\ " & 316 & , & \ldots\end{array}$

$\begin{array}{lllllll}\ldots & \ldots & \ldots & \ldots & \ldots & 22,750\end{array}$

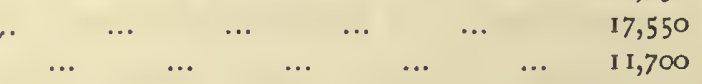

$\begin{array}{llllllll}. . & \ldots & \ldots & \ldots & \ldots & & 3,250\end{array}$

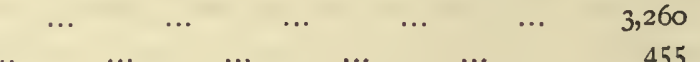

\section{EXPERIMENT IV.}

$\begin{array}{llllllll}\text { At time of mixing } \ldots & \ldots & \ldots & \ldots & \ldots & \ldots & \text { I30 }\end{array}$

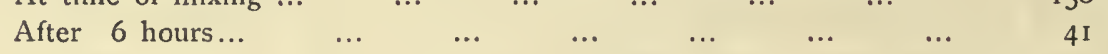

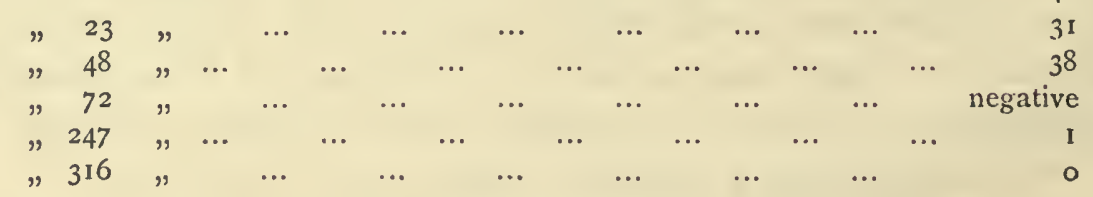

\section{EXPERIMENT V.}

$\begin{array}{lllllllll}\text { At time of mixing } & \ldots & \ldots & \ldots & \ldots & \ldots & \ldots & 31,200\end{array}$

$\begin{array}{rrrrrrrrrr}\text { After } 172 \text { hours } & \ldots & \ldots & \ldots & \ldots & \ldots & \ldots & 9,360\end{array}$

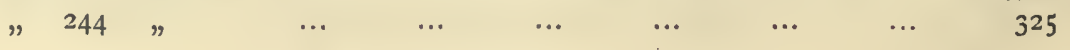




\section{EXPERIMENT VI.}

$\begin{array}{lllllllll}\text { At time of mixing } \ldots & \ldots & \ldots & \ldots & \ldots & \ldots & 325\end{array}$

$\begin{array}{llllllr}\text { After } 172 \text { hours } & \ldots & \ldots & \ldots & \ldots & \ldots & \ldots\end{array}$

EXPERIMENT VII.

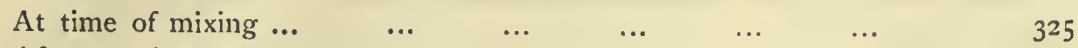

$\begin{array}{lllllll}\text { After } 504 \text { hours }\left(\text { water kept at } 8^{\circ}\right. & \text { C. }-10^{\circ} \text { C.) } & \ldots & \ldots & \ldots & 79\end{array}$

EXPERIMENT VIII.

$\begin{array}{llllllll}\text { At time of mixing } \ldots & \ldots & \ldots & \ldots & \ldots & \ldots & 325\end{array}$

$\begin{array}{llllllll}\text { After } 504 \text { hours } & \ldots & \ldots & \ldots & \ldots & \ldots & \ldots & 0\end{array}$

III.-The Infection of the Oyster with the B. Typhosus, and ITS Removal BY WaSHing.

These experiments were undertaken to ascertain whether oysters offered a favourable nidus for the multiplication of typhoid bacilli.

Healthy oysters were placed in large glass vessels containing sea-water, to which was added surface scrapings from agar plates previously inoculated with the typhoid bacillus.

By means of a syringe the water was aërated once or twice daily..

The contents of the stomach were pipetted out in the manner that will be indicated further on, and agar plates made; at the same time the water in which the oyster was placed was likewise analysed.

Table showing number of Organisms present in Stomach after infecting water.

\begin{tabular}{|c|c|c|c|c|c|}
\hline Oyster. & Inoculated. & Examined. & $\begin{array}{l}\text { No. of } \\
\text { Colonies. } \\
\text { Agar. }\end{array}$ & $\begin{array}{l}\text { Organisms } \\
\text { present } \\
\text { in Oysters. }\end{array}$ & $\begin{array}{l}\text { Number present in the } \\
\text { Sea-water. }\end{array}$ \\
\hline I & August 25 . & August 26. & $\mathbf{1}, 700$ & $\begin{array}{c}\text { Almost entirely } \\
\text { typhoid. }\end{array}$ & $\begin{array}{c}\text { Water in the same case } \\
585,000 \text { per c.c. }\end{array}$ \\
\hline 2 & " & $"$ & " & $"$ & \\
\hline 3 & $"$ & August 27. & 7,020 & , & $\begin{array}{l}\text { Water in the same case } \\
468,000 \text { per c.c. }\end{array}$ \\
\hline 4 & $"$ & August 28 . & $7, \infty 00$ & $"$ & $\begin{array}{c}\text { Water in same case } \\
40,950 \text { on agar, } \\
5,200 \text { on gelatine. }\end{array}$ \\
\hline 5 & August 26. & August 29. & 453 & $"$ & \\
\hline 6 & August 28 . & August 30. & 195 & , & Water in same case \\
\hline 7 & $"$ & September 4 . & 390 & $"$ & 2,047,500 per c.c. \\
\hline 8 & August $3 \mathrm{I}$. & $"$ & 325 & , & \\
\hline 9 & , & September ro. & 455 & " & \\
\hline
\end{tabular}

The above table shows that the typhoid bacillus does not increase in the body or in the tissues of the oyster. The figures would rather indicate, comparing the large number of bacilli present in the water with those found in the alimentary tract, that the bacilli perish in the intestine. We showed their presence up to ten days, and Dr. Klein up to two or three weeks. 
In the next series of experiments infected oysters were taken, the duplicates of which, as seen in the above table, contained comparatively large numbers of the $B$. typhosus. They were subjected to a running stream of pure clean sea-water. The result was definite and uniform; there was a great diminution or total disappearance of the B. typhosus in from one to seven days.

\begin{tabular}{|c|c|c|c|c|c|}
\hline Oyster. & Inoculated. & Washed. & Examined. & $\begin{array}{l}\text { No. of } \\
\text { Colonies. } \\
\text { Agar. }\end{array}$ & Kind of Organisms present. \\
\hline 1 & August 25 . & August 26. & August 30 . & 80 & 2 Colonies, B. typhosus. \\
\hline 2 & " & August 28 . & $"$ & 23 & B. typhosus present. \\
\hline 3 & August 26. & $"$ & $"$ & 44 & $"$ \\
\hline 4 & " & August 29. & " & 40 & " \\
\hline 5 & August 27. & $"$ & $"$ & 5 & , \\
\hline 6 & ", & " & August $3 \mathrm{I}$. & 700 & Abundant B. typhosus. \\
\hline 7 & August 28 . & August 30. & $"$ & 55 & B. typhosus present. \\
\hline 8 & August 26. & August 28 . & September 3 . & 4 & ? B. typhosus. \\
\hline 9 & August 27. & August 29. & $"$ & 10 & No B. typhosus found. \\
\hline 10 & " & $"$ & $"$ & 8 & 3 Colonies of B. typhosus. \\
\hline 11 & August 28 . & August 30 . & September 4 . & 4 & I Colony of B. typhosus. \\
\hline 12 & $"$ & September 3 . & $"$ & 200 & Majority $B$. typhosus. \\
\hline 13 & August 31 . & ? & $"$ & 4 & \\
\hline 14 & August 28 . & September 3 . & September 6. & 65 & No B. typhosus, but Proteus. \\
\hline 15 & August 31 . & $"$ & $"$ & 5 & ? B. typhosus. \\
\hline 16 & $"$ & September 5 . & " & 70 & One-half Colonies $B$. typhosus. \\
\hline 17 & " & September 3 . & September ro. & 1 & No B. typhosus. \\
\hline 18 & ” & September 5 . & September 11. & 2 & ? B. typhosus. \\
\hline
\end{tabular}

\section{IV.-The Bacteria present in the Alimentary Canal of the Oyster and the Mussel and other Shellfish.}

The method of analysis consisted in first cauterizing the mantle over the region of the stomach and then inserting a fine sterilized glass pipette; the pipette was moved about, and when sufficient of the contents of the stomach and the juices of the oyster had risen in the pipette, the latter was removed and its contents transferred to liquefied agar, ordinary gelatine, or sea-water gelatine, and plate cultivations made. In the first six cases examined (see Table, A-F) the oysters were especially fresh; in all the other cases the shellfish had been obtained hap-hazard from the various shops. In a very large proportion of cases $(1 / 3$ to $1 / 2$ ) the $B$. coli was isolated. In very many instances this organism was present in overwhelming numbers in the Petri dish. 
Table showing number of Colon-like Organisms isolated from 48 batches of Oysters.

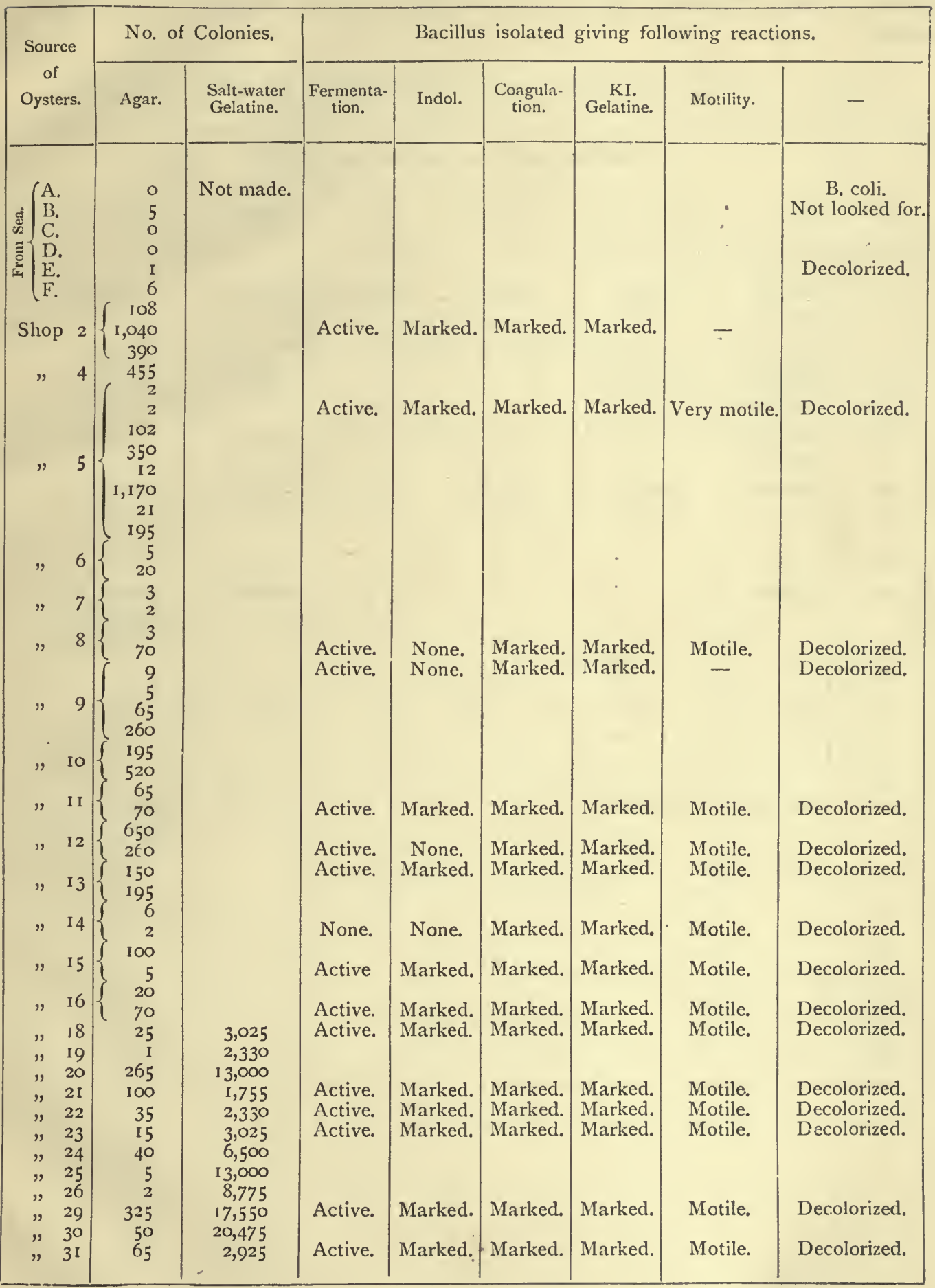


In a further series of experiments we examined nineteen batches of Oysters, seventeen batches of Mussels, eighteen batches of Cockles, five batches of Periwinkles, and one batch of Whelks: these were all obtained from shops in various parts of Liverpool.

Table II., showing Colon-like Organisms isolated from 19 batches of Oysters.

\begin{tabular}{|c|c|c|c|c|c|c|}
\hline \multirow[b]{2}{*}{ Oyster. } & \multicolumn{6}{|c|}{ Bacillus isolated giving following reactions. } \\
\hline & Motility. & Fermentation. & Milk. & Indol. & $\begin{array}{l}\text { Potato } \\
\text { growth. }\end{array}$ & Serum Reaction. \\
\hline 32 & $\begin{array}{l}\text { Actively } \\
\text { motile. }\end{array}$ & Marked. & Marked. & Marked. & Abundant. & Negative. \\
\hline 33 & Sluggish. & o & Peptonized. & Marked. & Abundant. & Negative. \\
\hline 34 & $\begin{array}{l}\text { Actively } \\
\text { motile. }\end{array}$ & Marked. & o & $\circ$ & Small. & Negative. \\
\hline 35 & $\begin{array}{l}\text { Actively } \\
\text { motile. }\end{array}$ & o & · & o & Visible. & Negative. \\
\hline 36 & Motile. & Marked. & Marked. & Marked. & Abundant. & Negative. \\
\hline 37 & o & o & o & o & o & o \\
\hline 38 & o & o & o & 0 & o & 0 \\
\hline 39 & Actively. & o & 。 & 0 & Abundant. & $\begin{array}{l}\text { Negative, forms } \\
\text { alkali in neutral } \\
\text { litmus whey. }\end{array}$ \\
\hline 40 & & & & & & \\
\hline $\begin{array}{l}4 \mathrm{I} \\
42 \\
43\end{array}$ & 0 & o & o & 0 & o & o \\
\hline 44 & Actively. & Marked. & $\circ$ & 0 & Abundant. & $\begin{array}{l}\text { Negative, forms } \\
\text { alkali in neutral } \\
\text { litmus whey. }\end{array}$ \\
\hline $\begin{array}{l}45 \\
46\end{array}$ & & & & & & \\
\hline $\begin{array}{l}47 \\
48\end{array}$ & o & o & o & o & o & o \\
\hline 49 & & & & & & \\
\hline 50 & & & & & & \\
\hline
\end{tabular}


THE BACTERIOLOGY OF THE OYSTER AND OTHER SHELLFISH.

Table III., showing Colon-like Organisms isolated from 18 batches of Mussels.

\begin{tabular}{|c|c|c|c|c|c|c|}
\hline Mussels. & Motility. & Fernientation. & Milk. & Indol. & $\begin{array}{l}\text { Potato } \\
\text { Growth. }\end{array}$ & Serum Reaction and Remarks. \\
\hline I & 0 & o & o & o & o & o \\
\hline 2 & o & o & 0 & o & o & o \\
\hline 3 & Active. & Marked. & Marked. & o & Abundant. & Negative, alkalinizes whey. \\
\hline 4 & & & & & & \\
\hline $\begin{array}{l}5 \\
6\end{array}$ & o & o & 0 & o & o & 0 \\
\hline 7 & Active. & o & o & o & Abundant. & $\begin{array}{l}\text { Negative, neutral reaction } \\
\text { in litmus whey. }\end{array}$ \\
\hline 8 & o & o & o & o & o & 0 \\
\hline 9 & o & o & Marked. & o & 0 & 0 \\
\hline 10 & Active. & o & 0 & o & Abundant. & $\begin{array}{l}\text { Negative, alkali in neutral } \\
\text { whey. }\end{array}$ \\
\hline 11 & Active. & Marked. & Marked. & o & Variable. & Negative, neutral reaction. \\
\hline 12 & & & & & & \\
\hline 13 & 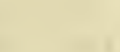 & & & & & . \\
\hline 14 & & & & & & \\
\hline 15 & o & o & o & o & o & o \\
\hline 16 & & & & & & \\
\hline 17 & & & & & & \\
\hline 18 & & & & & & \\
\hline
\end{tabular}

Table IV., showing Colon-like Bacilli isolated from i 8 batches of Cockles.

\begin{tabular}{|c|c|c|c|c|c|c|}
\hline Cockles. & Motility. & Fermentation. & Milk. & Indol. & Potato growth. & Remarks. \\
\hline $\begin{array}{r}1 \\
2 \\
3 \\
4 \\
5 \\
6 \\
7 \\
8 \\
\\
9 \\
10 \\
11 \\
12 \\
13 \\
14 \\
15 \\
16 \\
17 \\
18\end{array}$ & $\begin{array}{c}0 \\
0 \\
\text { Non-motile. }\end{array}$ & $\begin{array}{c}\text { o } \\
\text { Marked. } \\
\text { o } \\
\text { o }\end{array}$ & $\begin{array}{c}0 \\
\text { Marked. } \\
0 \\
0\end{array}$ & $\begin{array}{l}0 \\
0\end{array}$ & $\begin{array}{c}0 \\
0 \\
\text { Variable. }\end{array}$ & $\begin{array}{c}\text { o } \\
\text { o } \\
\text { Slight acid } \\
\text { reaction. }\end{array}$ \\
\hline
\end{tabular}


Result of examination of I batch of Whelks.

\begin{tabular}{|c|c|c|c|c|c|c|}
\hline Whelks. & Motility. & Fermentation. & Milk. & Indol. & $\begin{array}{c}\text { Potato } \\
\text { growth. }\end{array}$ & Remarks. \\
\hline I & & Slight. & 0 & 0 & Variable. & $\begin{array}{c}\text { Slight acid reaction } \\
\text { in neutral litmus } \\
\text { whey. }\end{array}$ \\
\hline
\end{tabular}

The 5 batches of periwinkles yielded no colon-like bacilli.

The second series of results tends to confirm those of the first. In some instances there was almost a pure culture of the colon bacillus, the plate cultivations giving a very characteristic odour. It will be seen from all the tables that the "colon-like" bacilli isolated differ in some of their reactions. There are numerous examples of typical colon-like bacilli, coagulating milk, forming indol, gas, and giving a decided acid reaction. But there are several cases in which the bacilli are active, do not coagulate milk nor form indol, with very slightly acid or sometimes alkaline reaction. In these cases, which by their reactions approached the typhoid-like type, the serum reaction was carefully applied, but in no case was a positive result obtained. This indifferent colon group is of considerable interest, for it is quite possible that it might be confused with true typhoid. The tables also show that the oyster is more frequently liable to the presence of "colon-like organisms" than the other species of common edible shellfish examined. It is difficult to say what may be the significance of the so frequent appearance of this group of organisms. Dr. Klein is of opinion that the presence of the $B$. coli in the oyster is strongly suggestive of fouling of the particular sample with material of excremental origin. We are not yet prepared to go so far as this until we have learnt more about the normal occurrence of this organism in the animal kingdom.

\section{V.-The occurrence of "Bacillus enteritidis sporogenes" in Shellfish.}

We have recently examined samples of shellfish (oysters, mussels, cockles, and periwinkles) from the Liverpool shops, and find amongst them the frequent occurrence of large spore-forming anaërobic bacilli with the characteristics of Klein's $B$. enteritidis sporogenes. The interest of this consists in the recent demonstration* by Dr. Klein, that this bacillus occurs in certain cases of diarrhœa, in sewage, in manure, \&c., and that its presence in articles of diet may be taken as presumptive evidence of facal contamination. The Medical Officer, in his last report to the Local Government Board, sums up the present position when he says, $\uparrow$ "He (Dr. Klein) has, he believes, ground for regarding this bacillus as primarily derived from excrement, and for considering its presence in water, earth, and the like, as a more trustworthy criterion of direct fæcal pollution than the presence merely of B. coli."

\footnotetext{
* Twenty-seventh Annual Report of the Local Government Board for 1897-98. Medical Officer's Supplement.
} 
We have considered it therefore of importance to examine specially for this organism a number of samples of oysters and other shellfish, as shown in the following table. The methods we have employed are these:- The shellfish have been carefully opened, and the water and "juices" surrounding the animal have been taken up in a sterilized pipette. A freshly-prepared milk tube, sterilized by boiling for one hour, is kept at a temperature of $80^{\circ} \mathrm{C}$., and then inoculated and kept at $80^{\circ} \mathrm{C}$. for fifteen minutes. The inoculated tube is then placed in a pyrogallate of soda tube (Buchner's method), and in addition the air replaced by running in hydrogen; the tube is firmly stoppered, and then transferred to the incubator and kept at $37^{\circ} \mathrm{C}$. Well-marked results were obtained in 24 hours.

One cubic centimetre of the whey from the above tubes was inoculated subcutaneously in the groin of guinea-pigs. The results were noted after 24 hours.

\begin{tabular}{|c|c|c|c|c|}
\hline Shellfish. & Sample. & $\begin{array}{l}\text { Action on Milk in absence } \\
\text { of Oxygen. }\end{array}$ & $\begin{array}{l}\text { Results of Inoculation } \\
\text { in Animals. }\end{array}$ & $\begin{array}{l}\text { Remarks on Microscopic } \\
\text { Preparations. }\end{array}$ \\
\hline Oysters. & I & Coagulation. No gas. & No effect. & $\begin{array}{l}\text { Short spore-bearing } \\
\text { bacilli present. }\end{array}$ \\
\hline „ & 2 & None. & - & \\
\hline , & 3 & None. & - & \\
\hline$"$ & 4 & $\begin{array}{l}\text { Coagulation. Gas } \\
\text { formed. }\end{array}$ & Local necrosis. & \\
\hline ” & 5 & $\begin{array}{l}\text { Slight coagulation. } \\
\text { Slight gas formation. }\end{array}$ & Swelling. & \\
\hline$"$ & 6 & $\begin{array}{l}\text { Marked coagulation. } \\
\text { Abundant gas. }\end{array}$ & Swelling. & \\
\hline " & 7 & None. & - & 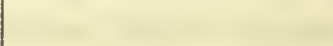 \\
\hline " & 8 & None. & - & \\
\hline$"$ & 9 & None. & - & \\
\hline , & 10 & None. & - & . \\
\hline " & II & None. & - & \\
\hline Mussels. & I & $\begin{array}{l}\text { Coagulation. Gas } \\
\text { formation. }\end{array}$ & Swelling. & $\begin{array}{c}\text { Large spore-bearing } \\
\text { anaërobic bacilli present }\end{array}$ \\
\hline$"$ & 2 & $\begin{array}{l}\text { Marked coagulation. } \\
\text { Gas formation. }\end{array}$ & Swelling. & Do. \\
\hline$"$ & 3 & Do. do. & Swelling. & \\
\hline , & 4 & Do. do. & Swelling. & \\
\hline$"$ & 5 & Do. do. & Nothing. & \\
\hline$"$ & 6 & None. & - & \\
\hline Cockles. & I & $\begin{array}{l}\text { Marked coagulation. } \\
\text { Gas formation. }\end{array}$ & $\begin{array}{l}\text { Extensive necrosis } \\
\text { and swelling. }\end{array}$ & Small bacilli present. \\
\hline$"$ & 2 & Do. do. & Do. & $\begin{array}{c}\text { Large spore-bearing } \\
\text { anaërobic bacilli present. }\end{array}$ \\
\hline$"$ & 3 & Do. do. & Do. & \\
\hline$"$ & 4 & $\begin{array}{l}\text { Slight coagulation. } \\
\text { No gas. }\end{array}$ & Slight local reaction. & \\
\hline Periwinkle.* & I & $\begin{array}{l}\text { Coagulation. Gas } \\
\text { formation. }\end{array}$ & Slight swelling. & $\begin{array}{l}\text { Large spore-bearing } \\
\text { anaërobic bacilli present. }\end{array}$ \\
\hline
\end{tabular}

* Large Littorina littorea from the west coast of Scotland. 
This Table indicates that, so far as regards anaërobic milk-coagulating bacilli, oysters as bought in the town shops are considerably better than the other shellfish. The inoculations, however, were not in any case followed by death within 24 hours; while simultaneous experiments, in which the anaërobic milk-coagulating, spore-bearing bacilli were isolated from sewage, gave fatal results in that time. We are thus not yet prepared to say whether the bacilli from the shellfish are distinct from $B$. enteritidis, or represent attenuated (less virulent) conditions of Klein's form.

It is evident from the result of these experiments, and a consideration of all the facts brought to light in recent years in regard to the bacteriology of shellfish and its influence on public health, that we must regard oysters, mussels, cockles, and the like as nutritious food matters which, from their nature and the circumstances of their cultivation and sale, are liable to become contaminated with organisms-pathogenic or otherwise-and their deleterious products.

Once this is recognised the practical applications are largely a matter of common sense. Shellfish must not be taken as food from grounds where there is any possibility of sewage contamination; after removal from the sea, while in transit, in store, or in market, they should be carefully protected from any possibility of insanitary environment; they should not be kept longer than is absolutely necessary in shops, cellars, \&c., in towns, where, even if not running the risk of fresh contamination, they are under conditions favourable to the reduction of their vitality. and the growth of their bacterial contentsthe fresher they are from the sea the more healthy they are likely to be ; finally, only absolutely fresh shellfish should be eaten uncooked, and those that are cooked must be sufficiently cooked, raised to boiling point and kept there for at least ten minutes. 


\section{XIV.-_CONCLUSIONS.}

I. Although our primary object was to study the oyster under unhealthy conditions, in order to elucidate its supposed connection with infective disease, we found it necessary to investigate in minute detail the histology of certain parts of the bodyespecially the gills and mantle-lobes, the alimentary canal and the liver. We give figures and descriptions of parts of these structures in both normal and abnormal conditions.

2. We have also worked out the distribution and probable function of a minute muscle, which we believe to be the modified representative of the protractor pedis muscle of some other Molluscs.

3. A diseased condition we found in some of our experimental oysters very soon brought us in contact with the vexed question of "greening" in oysters, and one of the first results we arrived at was that there are several distinct kinds of greenness in oysters. Some of these, such as the green Marennes oysters and those of some rivers on the Essex coast, are healthy; while others, such as some Falmouth oysters containing copper, and some American oysters re-bedded on our coast, and which have the pale green leucocytosis we described in a paper to the Royal Society, are not in a healthy state.

4. Some forms of greenness (e.g., the leucocytosis) are certainly associated with the presence of a greatly increased amount of copper in the oyster; while other forms of greenness (e.g., the Marennes) have no connection with copper, but depend upon the presence of a special pigment (marennin), which may possibly be associated with a certain amount of iron.

5. We see no reason to think that the iron in the latter case is taken in through the surface epithelium of the gills and palps, but regard it, like the rest of the iron in the body, as a product of ordinary digestion and absorption in the alimentary canal and liver.

6. We do not find that there is any excessive amount of iron in the green Marennes oyster compared with the colourless oyster, nor do the green parts (gills, palps, \&c.) of the Marennes oyster contain, either absolutely or relatively to the colourless parts (mantle, \&c.), more iron than colourless oysters. We therefore conclude that there is no connection between the green colour of the "Huitres de Marennes" and the iron they may contain.

7. On the other hand, we do find by quantitative analysis that there is more copper in the green American oyster than in the colourless one; and more proportionately in the greener parts than in those that are less green. We therefore conclude that their green colour is due to copper. We also find a greater quantity of iron in these green American oysters than in the colourless; but this excess is, proportionately, considerably less than that of the copper. 
8. In the Falmouth oysters, containing an excessive amount of copper, we find that much of the copper is certainly mechanically attached to the surface of the body, and is in a form insoluble in water, probably as a basic carbonate. In addition to this, however, the Falmouth oyster may contain a much larger amount of copper in its tissues than does the normal colourless oyster. In these Falmouth oysters the cause of the green colour may be the same as in the green American oyster.

9. By treating sections of diseased American oysters under the microscope with potassium ferrocyanide and various other reagents, we find that the copper reactions correspond in distribution with the green colouration; and we find, moreover, from these micro-chemical observations that the copper is situated in the blood-cells or leucocytes, which are greatly increased in number. This condition may be described as a green leucocytosis, in which copper in notable amount is stored up in the leucocytes.

IO. We find that an aqueous solution of pure hæmatoxylin is an extremely delicate test for copper, just as Macallum found it to be for iron.

I I. Experiments in feeding oysters with weak solutions of various copper and iron salts gave no definite results-certainly no clear evidence of any absorption of the metals accompanied by "greening."

12. Although we did not find the Bacillus typhosus in any oysters obtained from the sea or from the markets, yet in our experimental oysters inoculated with typhoid we were able to recover the organism from the body of the oyster up to the tenth day. We show that the typhoid bacillus does not increase in the body or in the tissues of the oyster, and our figures indicate that the bacilli perish in the intestine.

I3. Our experiments showed that sea-water was inimical to the growth of the typhoid bacilli. Although their presence was demonstrated in one case on the 2 Ist day after addition to the water, still there appeared to be no initial or subsequent multiplication of the bacilli.

14. In our experiments in washing infected oysters in a stream of clean sea-water the results were definite and uniform : there was a great diminution or total disappearance of the typhoid bacilli in from one to seven days.

15. The colon group of bacilli is frequently found in shellfish as sold in towns, and especially in the oyster; but we have no evidence that it occurs in Mollusca living in pure sea-water. The natural inference, that the presence of the colon bacillus invariably indicates sewage contamination, must, however, not be considered established without further investigation.

16. The colon group may be separated into two divisions-(I) those giving the typical reactions of the colon bacillus, and (2) those giving corresponding negative reactions, and so approaching the typhoid type; but in no case was an organism giving all the reactions of the $B$. typhosus isolated. It ought to be remembered, however, that our samples of oysters, although of various kinds and from different sources, were in no'case, so far as we are aware, derived from a bed known to be contaminated or suspected of typhoid. 
17. We have shown the frequent presence, in various shellfish, of anaërobic sporebearing bacilli showing the characteristics of the $B$. enteritidis sporogenes recently described by Klein.

I8. Consequently, as the result of our investigations and the consideration of much evidence, both from the Oyster Growers and the Public Health Officer's point of view, we beg to recommend-

(a) That the necessary steps should be taken to induce the oyster trade to remove any possible suspicion of sewage contamination from the beds and layings from which oysters are supplied to the market. This could obviously be effected in one of two ways : either (I) by restrictive legislation and the licensing of beds only after due inspection by the officials of a Government Department ; or (2) by the formation of an Association amongst the Oyster Growers and Dealers themselves, which should provide for the due periodic examination of the grounds, stores, and stock, by independent, properly qualified inspectors. Scientific assistance and advice given by such independent inspectors would go far to improve the condition of the oyster-beds and layings, to reassure the public, and to elevate the oyster industry to the important position which it should occupy.

(b) Oysters imported from abroad (Holland, France, or America) should be consigned to a member of the suggested "Oyster Association," who should be compelled by the regulations to have his foreign oysters as carefully inspected and certified as those from his home layings. A large proportion of the imported oysters are, however, deposited in our waters for such a period before going to market, that the fact of their having originally come from abroad may be ignored. If this period of quarantine were imposed upon all foreign oysters, a great part of the difficulty as to inspection and certification would be removed.

(c) The grounds from which mussels, cockles, and periwinkles are gathered should be periodically examined by scientific inspectors in the same manner as the oyster-beds. The duty of providing for this inspection might well, we should suggest, be assumed by the various Sea Fisheries Committees around the coast.*

* Since the above was written, and published in a preliminary abstract of this memoir, we are glad to learn that (I) the "British Oyster Industries Association" has been formed, and (2) an Oyster Bill has been laid before Parliament. If the Association takes a sufficiently high view of its responsibilities and duties, the provisions of the Bill will become unnecessary. 


\section{EXPLANATION OF THE PLATES.}

The figures have been drawn either by ourselves, or under our immediate direction and supervision in our laboratories. The colours are not diagrammatic, but represent accurately the natural conditions and the effects of differential staining or chemical reactions.

Most of the histological work has been done with the Zeiss $\frac{1}{12}$ oil immersion and the Apochromatic $\cdot \mathrm{I} .5 \mathrm{~mm}$. and $2 \mathrm{~mm}$. objectives, with the compensating ocular I 2 . Some of the figures have been drawn as seen under other powers, as indicated in the explanations.

\section{PLATE I.}

\section{ILLUSTRATING THE GILL.}

Fig. I.-Diagram of the Anatomy of the Oyster (Ostrea virginica, $\mathrm{Gm}$.) from the left side, natural size. $A$. anterior ; $P$. posterior ; $D$. dorsal ; $V$. ventral ; $a$. anus; $a d d$. and $a d d .1$ the two parts of the adductor muscle; au. auricles of heart ; $b r$. the two pairs of gills; c.g. cerebral ganglion; cr.s. crystalline style in first portion of intestine; $h . d$. one of the hepatic ducts opening into stomach ; $i$. intestine ; $i . l$. the narrow intestinal loop ; $l$. liver ; lig. ligament ; m. mouth ; p.p. l $^{\prime}$ anterior and posterior labial palps; $p . m$. end of reduced protractor pedis muscle; $p . h$. pre-oral hood of mantle or cucullus; pall. pallium or mantle; $r$. rectum; sh. shell; st. stomach; u. umbo of shell; u.g.a. urino-genital aperture; $v$. ventricle of heart, in pericardium; v.g. visceral ganglion.

Fig. 2. - Transverse section of part of a single branchia, to show its two lamella, their closely folded condition, and the large skeletal bars $(x 40)$.

Fig. 3.-Transverse section across two crests of a single branchia, to show the gill filaments, an interlamellar junction, and the arrangement of the water and blood spaces. (Leitz, obj. 7).

Fig. 4. - A few gill filaments from one lamella, seen in section, to show their histology. (Zeiss, obj. $\frac{1}{12}$ ).

Fig. 5.-A few similar gill filaments from a Dutch green oyster (Nieuport, Jan. 19, 1897), to show the distribution of the eosinophilous macroblasts. (Zeiss, obj. $\frac{1}{12}$ ).

Fig. 6.--Piece of living gill of pale green "Native" oyster from West Mersea (Feb. 25, 1896), to show the active cilia and the green macroblasts. (Swift, I inch obj.)

Fig. 7. - The green macroblasts on three adjacent gill filaments. (Swift, $\frac{1}{4}$ inch obj.)

Fig. 8. - Row of macroblasts seen in profile. (Swift, $\frac{1}{4}$ inch obj.)

Fig. 9. - Two adjacent gill filaments to show macroblasts $(m)$ and granular leucocytes $(l)$. (Zeiss, $1^{2} \frac{2}{2}$ oil immersion).

Fig. 10.-A macroblast and two adjacent epithelial cells. (Zeiss, apochromatic.)

Fig II.-Blood-cells from gill (Zeiss, apochromatic $1.5 \mathrm{~mm}$.)

Fig. 12.-Piece of free edge of gill of American oyster (June 8, 1898) showing leucocytes aggregated in numbers.

Fig. 13.--Another place on edge of gill showing the leucocytes migrating out. (Swift, $\frac{1}{6}$ inch obj.) 
PLATE II.

\section{ILLUSTRATING THE REDUCED PROTRACTOR PEDIS MIUSCLE, \&C.}

Fig. 1.-American oyster, with half of the left valve (c.s.) removed, to show the insertion of the reduced pedal muscle at $s p$.

Fig. 2.--American oyster, with well-marked "spot" ( $s p$.) formed by pedal muscle.

Fig. 3.-Another specimen, with the edge of the spot strongly pigmented $(\times 2)$.

Fig. 4. - Section across the adductor impression of the shell $\left(x_{2}\right)$. The thin black line is dark brown pigment.

Fig. 5.-One end of a similar section magnified: $a$, prismatic layer ; $b$, opaque chalky layer ; $c$, transparent columnar lining to adductor impression; $d$, brown pigment (Swift, obj. I inch).

Fig. 6. - Three sections across the impression formed on shell by insertion of pedal muscle. The smaller black marks are brown pigment $(\times 2)$.

Fig. 7.-One end of a similar section magnified. Lettering as in Fig. 5 (Swift, obj. I inch).

Fig. 8.-Epithelium on surface of mantle near "spot," for comparison with,

Fig. 9.-Modification of surface of mantle at "spot" (Leitz, obj. 7).

Fig. 10.-Section showing the fibres of the pedal muscle leaving the spot and running inwards and backwards (Leitz, obj. 3).

Fig. II.-Section further back, showing the muscle fibres coming into close relation with the large blood sinus (lac.) and with the renal tubules.

Fig. 12.-Section still further back, showing the fibres cut nearly transversely, and now lying below the blood sinus and near the liver tubules.

Fig. 13.-Last section of the series, showing the distribution of the muscle fibres along the top of the anterior end of the external gill (all Leitz, obj. 3).

Fig. :4.-Diagram to show the action of the modified protractor pedis muscle ( $p r$.) in widening the two ciliated food avenues (see arrowes) leading to the mouth ( $m$. .).

\section{PLATE III.}

\section{ILLUSTRATING THE LIVER, \&..}

Fig. I.-Oblique section of the visceral mass and gills of an oyster, to show relations of stomach (st.), liver $(l$.$) , pallial lobes (pall.), and the 4$ branchiæ $(b r$.$) , natural size.$

Fig. 2.- Section of a visceral mass, to show a dark coloured liver, natural size.

Fig. 3.-Similar section showing a light yellow brown liver, natural size.

Fig. 4. - Low-power view of a section of visceral mass of a green Dutch oyster, to show stomach (st.), intestine (i.i.), liver ducts (d.d.d.), and cæeca of liver (c.c.c.); (Swift, obj. I inch).

Fig. 5.- Section showing the opening of a liver duct into the stomach (Leitz, obj. 3).

Fig. 6.-Longitudinal section of a liver cæcum (Leitz, obj. 7).

Fig. 7.-Transverse section of a liver cæcum (Leitz, obj. 7).

Fig. 8. -Transverse section of a well-formed liver cæcum of a green Dutch oyster (Leitz, obj. 7).

Fig. 9. - Three liver cells from the last, showing green granules in the cells (Zeiss, apochr. I'5 mm.).

Fig. 10.-Section of a group of healthy, well-formed liver cæca (Zeiss, 1. obj.).

Fig. 11.-Section of a group of shrunken, degenerate liver cæca, from a sickly Fleetwood American oyster (Zeiss, $\frac{1}{12}$ obj.).

Fig. 12.-Hepatic cells (h.c.), basal cells or "Fermentzellen" (b.c.), connective tissue (c.t.), green leucocyte $(l$.$) , from liver cæcum of green oyster with green granules (g n . g r \cdot)$ in the liver cells. (Zeiss, apochr. $1.5 \mathrm{~mm}$.). 


\section{PLATE III.-continued.}

Fig. 13.-Section showing stomach wall, liver duct, and cæca (Swift, obj. $\frac{1}{4}$ inch).

Fig. 14. - Epithelium of stomach wall (Zeiss, obj. $\frac{1}{1^{\frac{1}{2}}}$ ).

Fig. 15.-Epithelium of a larger liver duct (Zeiss, obj. $\frac{1}{12}$ ).

Fig. 16.-Epithelium of one of the smallest branches of the liver duct (Zeiss, obj. $1^{\frac{1}{2}}$ ).

Fig. 17.-Section of stomach wall of a green oyster, showing green pyriform macroblasts (Zeiss, obj. $\frac{1}{12}$ ).

Fig. I8.-Section to show the migration of leucocytes through the stomach wall (Leitz, obj. 7).

Fig. 19.-Section of stomach of green Dutch oyster, to show large eosinophilous granular cells (eos), and also green granular leucocytes (g.l.) migrating through the stomach wall (Leitz, obj. 7).

\section{PLATE IV. \\ ILLUSTRATING GREEN OYSTERS.}

Fig. I. - "Huitre de Marennes," with the right valve removed, and the mantle lobe partly reflected, to show the dark blue-green colour of the gills, natural size.

Fig. 2.-A small part of the gill enlarged with a lens, to show the vertical gill filaments arranged in three crests and two troughs.

Fig. 3.-A series of adjacent filaments examined alive to show the arrangement of the large macroblasts, and also some amœboid cells on the surface (Leitz, obj. 7).

Fig. 4. - The macroblasts in situ, more highly magnified, from filaments fixed in formaline, and teased (Zeiss, $\frac{1}{1 \frac{1}{2}}$ oil im.).

Fig. 5.-Epithelium of the intestinal wall of Marennes oyster, to show the pyriform green granular cells (Zeiss, $\mathrm{i}^{1} \frac{1}{2}$ oil $\mathrm{im}$.).

Fig. 6.-Large Dutch oyster, showing the pale green gills.

Fig. 7.-External surface of mantle of an oyster from Nieuport, to show large granular eosinophilous cells, and also green granules in the epithelium (Zeiss, obj. $\frac{1}{12}$ ).

Fig. 8. -Another section of same to show large green granules under the epidermis (Zeiss, obj. $\frac{1}{12}$ ).

Fig. 9. - "Native" from the Roach River, to show the pale green gills.

Fig. Io.-Section of intestine of green Nieuport oyster, unstained and examined fresh to show colour of epithelium and liver tubules (Swift, I inch).

Fig. II.-American oyster, living in sea-water after removal of left valve, to show corrugation of mantle lobe, and spotting of mantle and adductor muscle with masses of green leucocytes.

\section{PLATE V. \\ ILLUSTRATING THE HISTOLOGY.}

Fig. 1.-Section of edge of the mantle of Fleetwood American oyster, in which there is the green leucocytosis; showing vacuolated and disorganised epithelium through which the large granular leucocytes have been migrating (Zeiss, $\frac{1}{12}$ oil $\mathrm{im}$. ).

Fig. 2.-Section showing external surface of mantle in Marennes oyster, showing large eosinophilous cells (Zeiss, apochr. I. 5 mm.).

Fig. 3.-Transverse section of part of gill filament in Marennes oyster, showing eosinophilous cells (Zeiss, apochr. $1.5 \mathrm{~mm}$.).

Fig. 4.-Eosinophilous cells in the epithelium and in the sub-epithelial connective tissue of Nieuport oyster (Zeiss, apochr. $1.5 \mathrm{~mm}$.). 


\section{PLATE V.-continued.}

Fig. 5.-Section showing external surface of mantle of Nieuport oyster, showing eosinophilous cells passing outwards (Zeiss, apochr. I. $5 \mathrm{~mm}$.).

Fig. 6.-Transverse section of pallial tentacle of Dutch oyster, showing eosinophilous cells (Leitz, obj. 7).

Fig. 7.-Section of internal surface of mantle of American oyster, showing eosinophilous cells (Zeiss, apochr. $1.5 \mathrm{~mm}$.).

Fig. 8.-Another section of the same, to show the hæmatoxylin reaction in the eosinophilous cells.

Fig. 9.-Large amœboid granular green leucocytes from the surface of gill and mantle in American oyster, with the green leucocytosis, bedded at Fleetwood. The four marked $b$ were from the blood, the rest from the surface (Zeiss, apochr. $1.5 \mathrm{~mm}$.).

Fig. 10.-Leucocytes lying between the liver tubules stained with pure hæmatoxylin (Zeiss, $\frac{1}{12}$ ).

Fig. 11.-Transverse section of a gill filament of green "native" from Roach River (Zeiss, apochr. 1.5 mm.).

Fig. 12.-Section of the liver of an American oyster with the green leucocytosis, showing the hæmatoxylin reaction given by the leucocytes $(x 60)$.

\section{PLATE VI.}

\section{ILLUSTRATING THE GREEN LEUCOCYTOSIS IN AMERICAN OYSTERS.}

Fig. I.-A healthy well-grown "East River" American oyster.

Fig. 2. - The same with shell valve removed from right side, to show the nearly colourless mantle.

Fig. 3.-A similar American oyster (from Liverpool market, May 17, 1897) with left valve removed, to show the green leucocytosis. Engorged green blood channels are seen over the viscera and on the mantle edge, and the auricles of the heart are filled with green leucocytes.

Fig. 4. - Left side of another similar oyster (Liverpool market, May 18, 1897), where the pallial blood channels are very completely injected with green leucocytes.

Fig. 5. -Group of Portuguese oysters (Ostrea angulata), one of which is opened to show the green leucocytosis (July 1897).

Fig. 6.-An American oyster (O. virginica) re-bedded at Fleetwood, to show a completely green mantle (March 30, 1897).

Fig. 7.-Another, to show a completely green heart and a bright patch on mantle over viscera.

Fig. 8.-An English oyster (O. edulis) from Falmouth (July 3, I897), to show the ventricle of the heart completely green, and the auricles brown.

Fig. 9. - Small Dutch oyster (O. edulis), to show green spots scattered over the mantle and adductor muscle (July 26, I897).

\section{PLATE VII.}

\section{ILLUSTRATING THE COPPER REACTIONS IN GREEN OYSTERS.}

Fig. 1.-Part of the mantle of a green American oyster (May 27, 1897) showing the engorged blood channels and smaller blood spaces in the connective tissue, coloured red-brown after treatment with potassium ferrocyanide (Zeiss, $35 \mathrm{~mm}$.).

Fig. 2.-Two ventricles of American oysters, one $(B)$ green and one $(A)$ colourless, shown fresh and also after treatment with potassium ferrocyanide.

Fig. 3.-Preparation of blood of green oyster, after treatment with potassium ferrocyanide, to show some of the leucocytes coloured red (Zeiss, obj. D). 


\section{PLATE VII.-continued.}

Fig. 4.-Small piece of the mantle of green American oyster, after treatment with potassium ferrocyanide, and then left overnight in clove oil to clear, showing an engorged blood channel stained red (Swift, I inch obj.).

Fig. 5. - Section of the mantle edge of green American oyster, showing an engorged blood space, coloured after treatment with potassium ferrocyanide.

Figs. 6, 7, 8, 9.-Four similar sections of the mantle edge of a green American oyster, showing a large blood space engorged with green leucocytes (Zeiss, $35 \mathrm{~mm}$.).

Fig. 6.-Unstained, showing the dull green tint.

Fig. 7.-After potassium ferrocyanide.

Fig. 8.-After ammonium sulphide.

Fig. 9.-After pure hæmatoxylin.

\section{PLATE VIII.}

\section{ILLUSTRATING THE HISTO.CHEMICAL REACTIONS.}

Fig. 1.-Leucocytes in the mantle of the American green oyster, unstained (Zeiss, apochr. $2 \mathrm{~mm}$.).

Fig. 2.-Another part of the same, treated with pure hæmatoxylin (Zeiss, apochr. 2 mm.!

Fig. 3.-The same, treated with potassium ferrocyanide (Zeiss, apochr. $2 \mathrm{~mm}$.).

Fig. 4. - The same, treated with anmonium sulphide (Zeiss, apochr. 2 mm.).

Fig. 5.-A blood space in the mantle filled with leucocytes, treated with potassium ferrocyanide (Swift, $\frac{1}{6}$ inch).

Fig. 6.-A similar blood space, treated with pure hæmatoxylin (Swift, $\frac{1}{6} \mathrm{inch}$ ). 


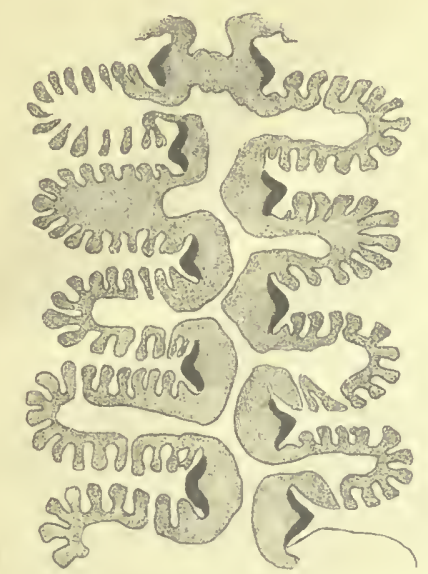

Fig. 2.
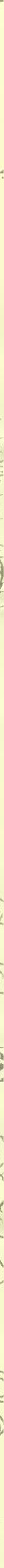

Fig. 6.

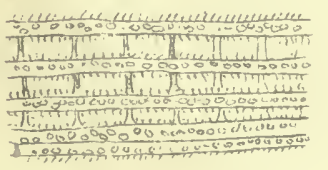

Fing 7.

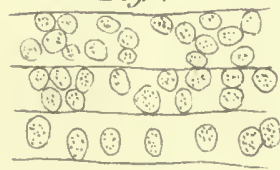

Fing. 8.
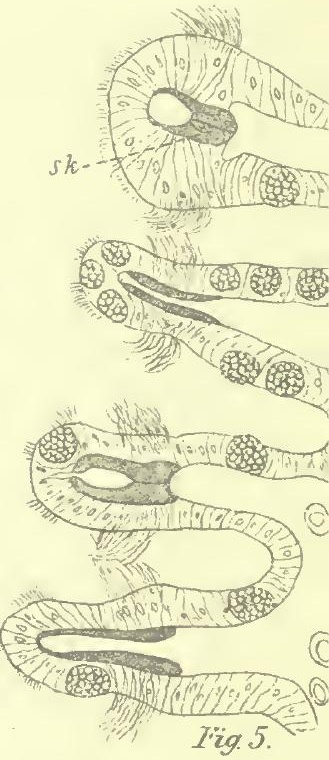

32 .

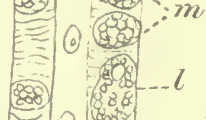

rig. 5. 



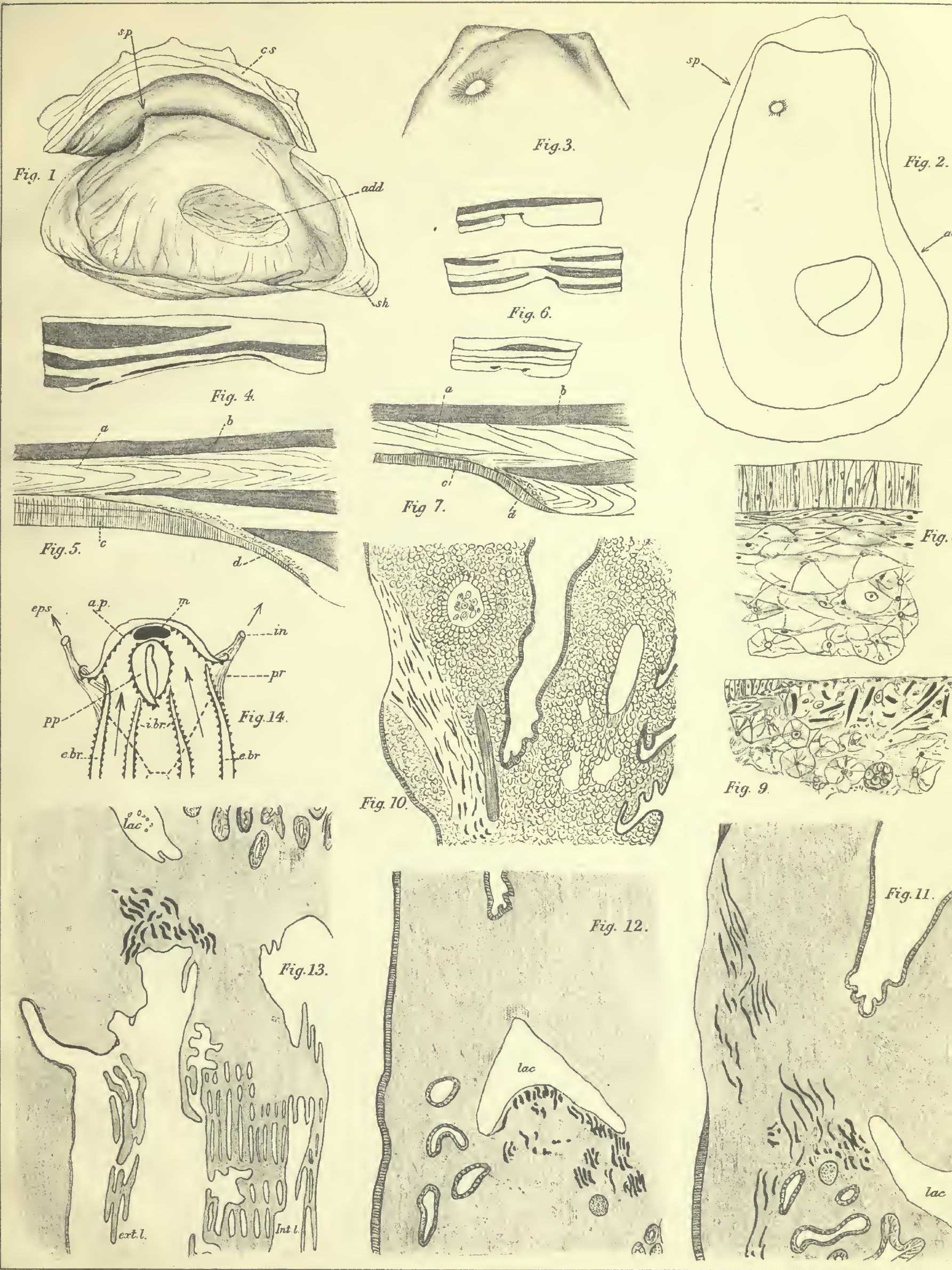





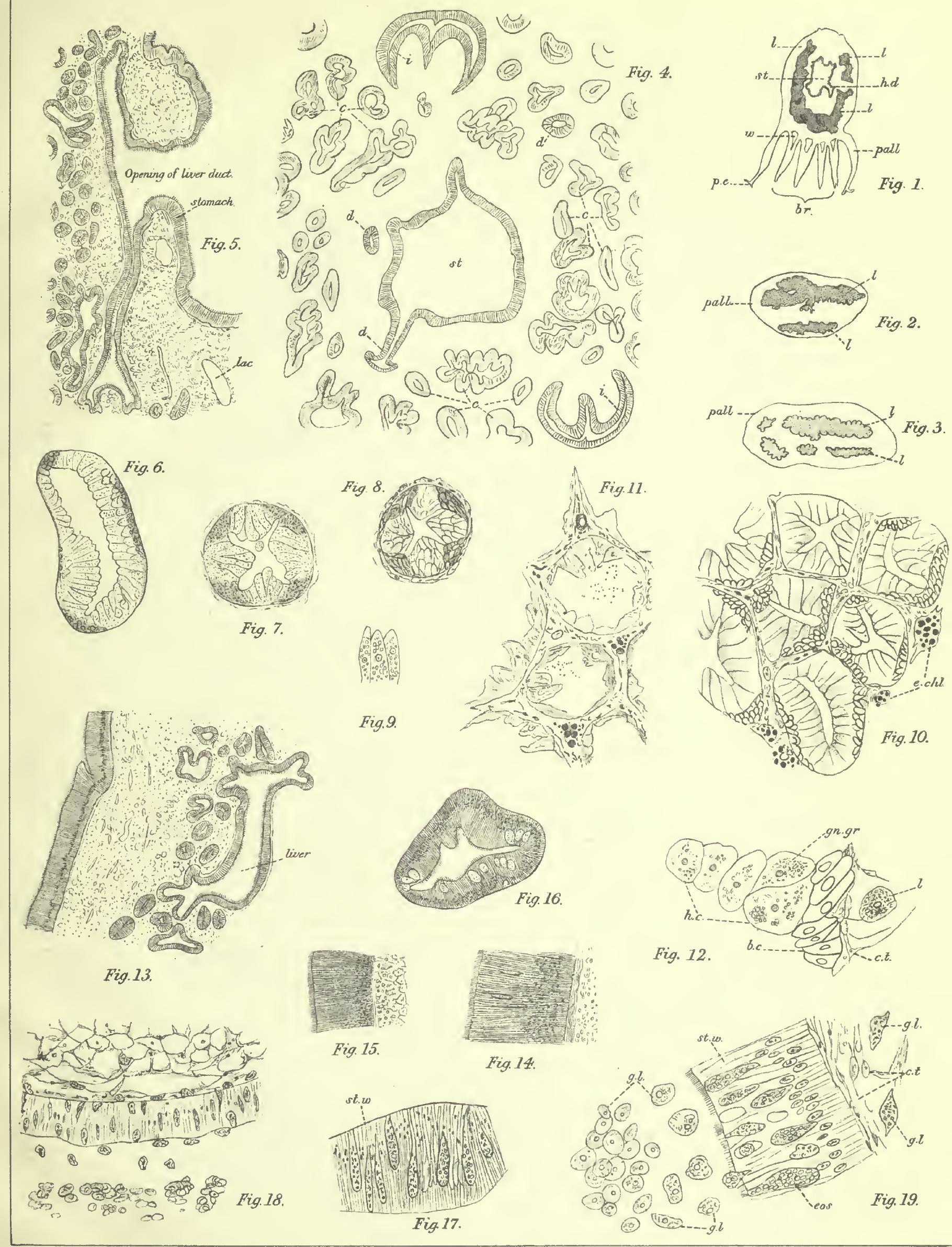





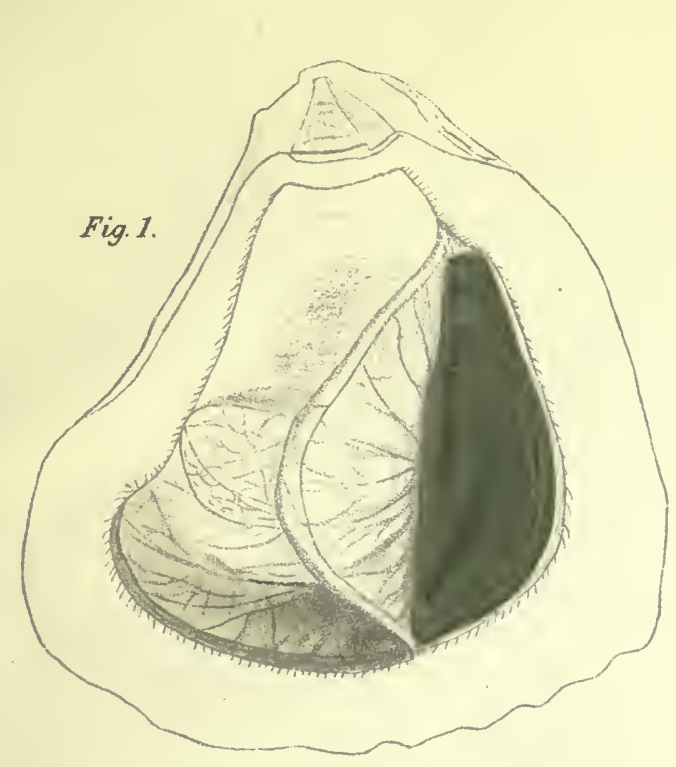

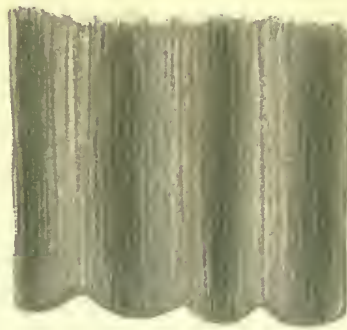

Fig. 2.

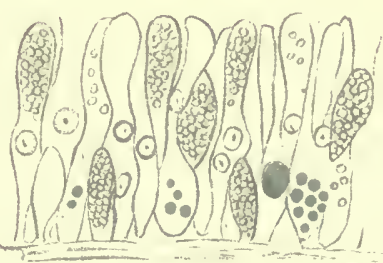

Fig. 5.

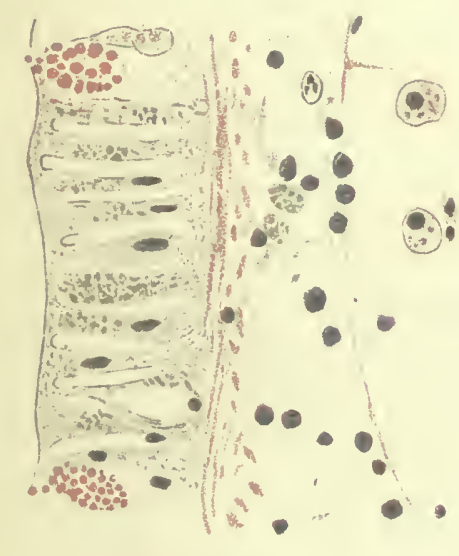

Frg.7.

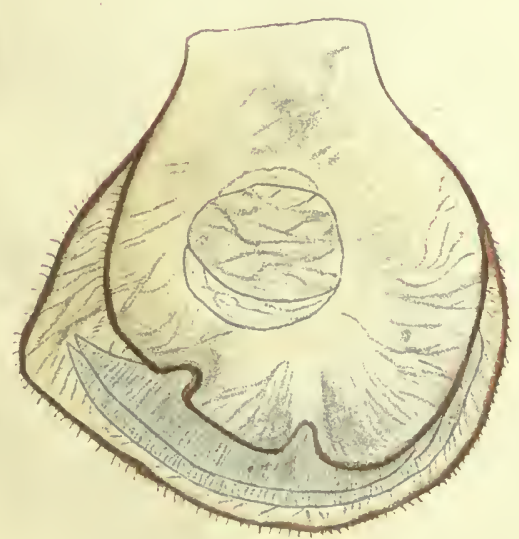

Fig. 9.

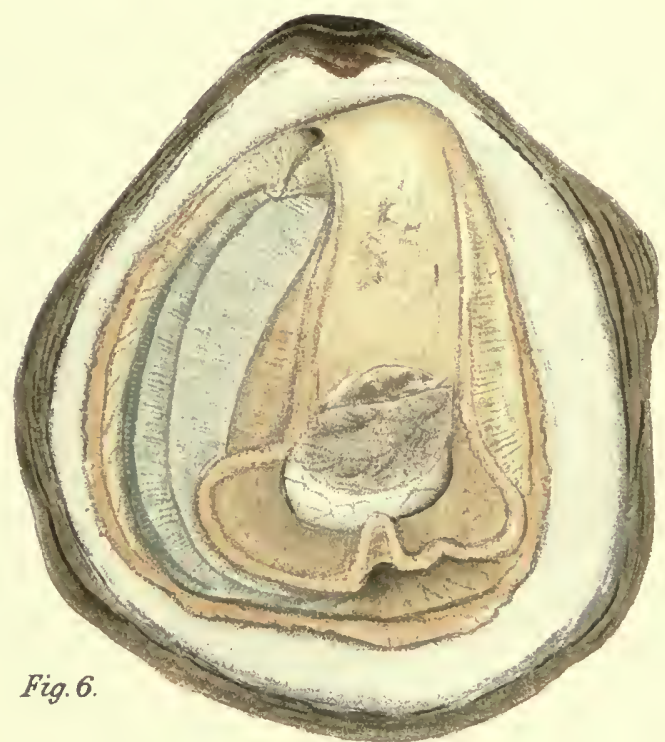

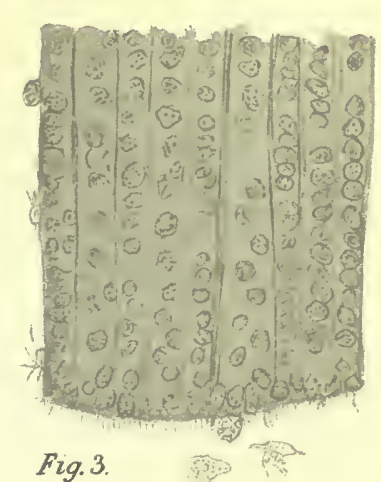

Fig. 3.

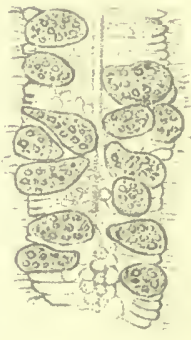

Fig.

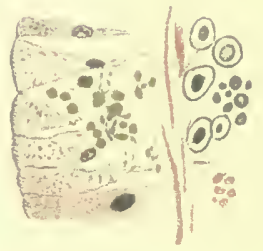

Fig. 8 .

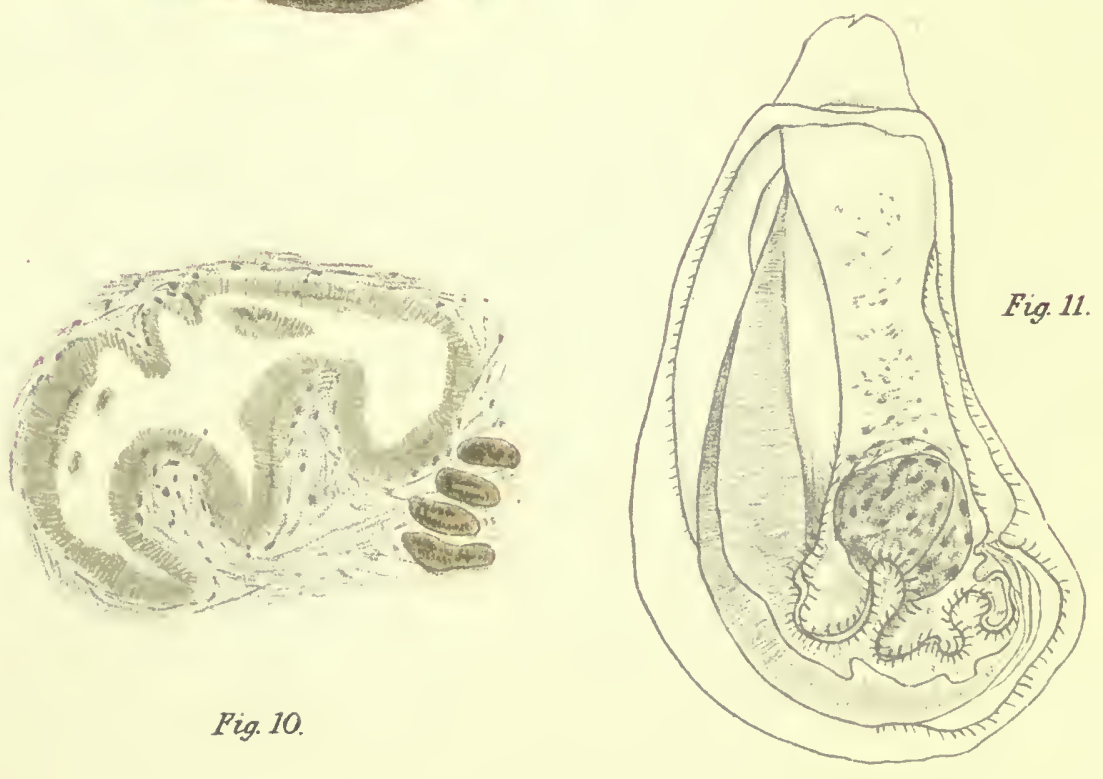




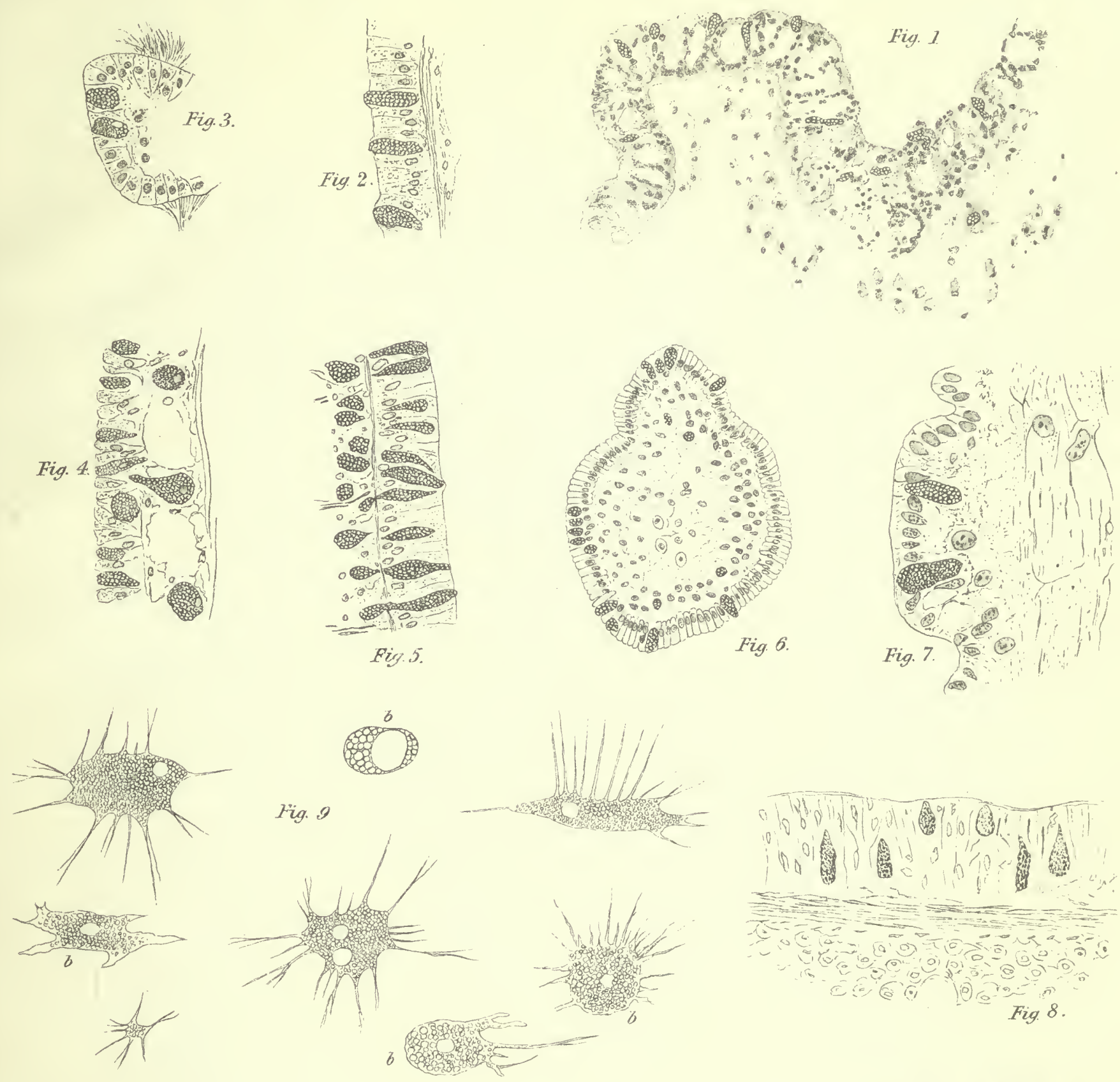

Fig. 8.
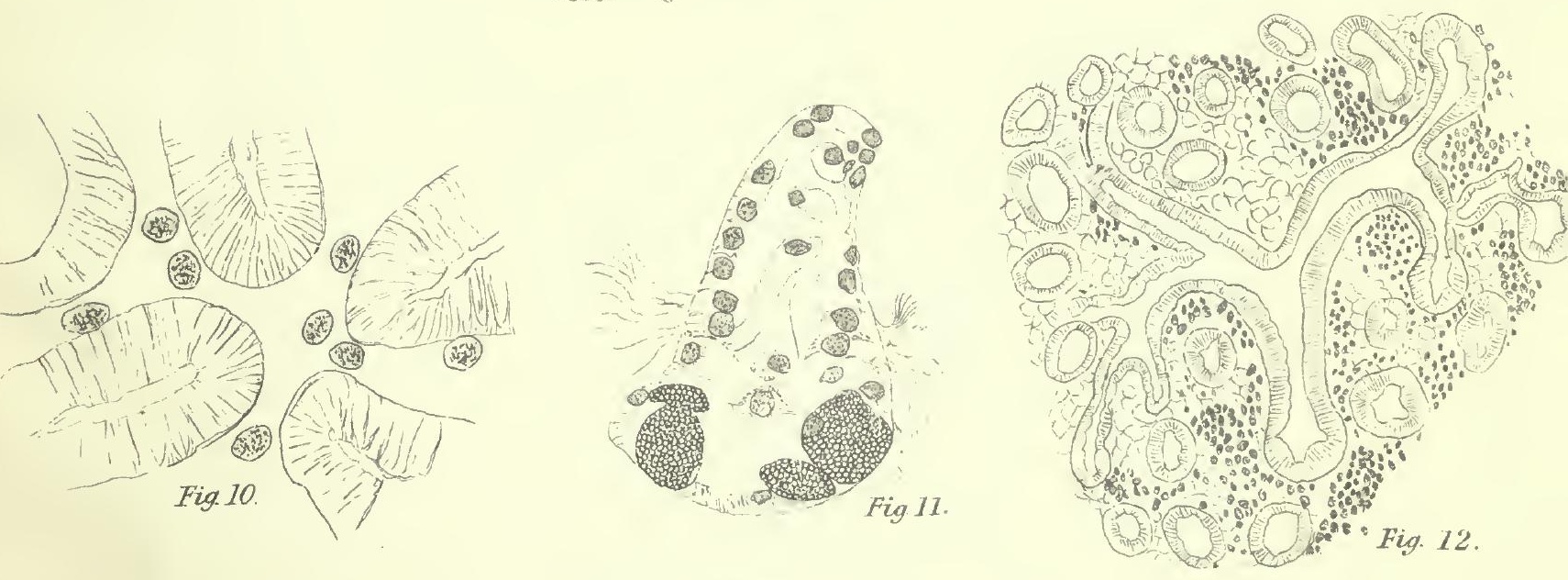
<smiles>[CH]C</smiles> 

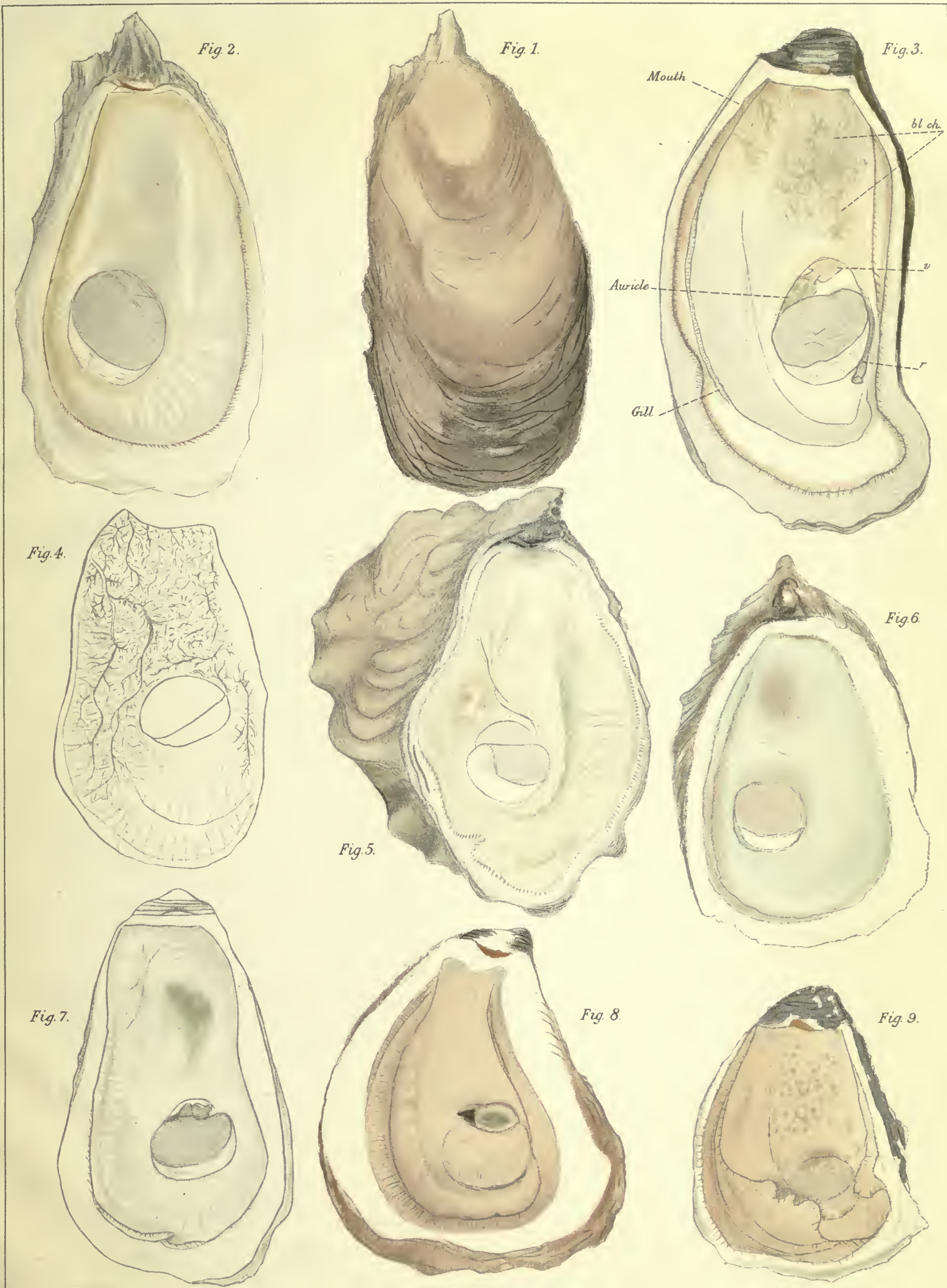


3

$$
\begin{aligned}
& \text { 3. } \\
& \text { 政 } \\
& \text { a }
\end{aligned}
$$

Fin. 1

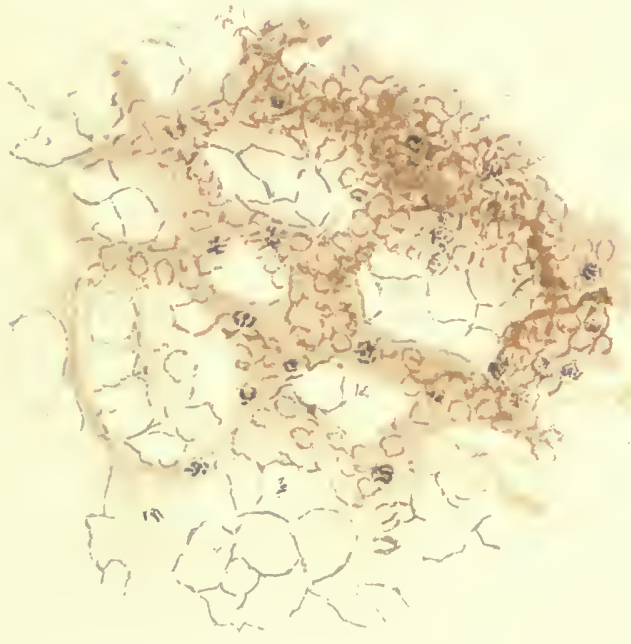

Fig.3

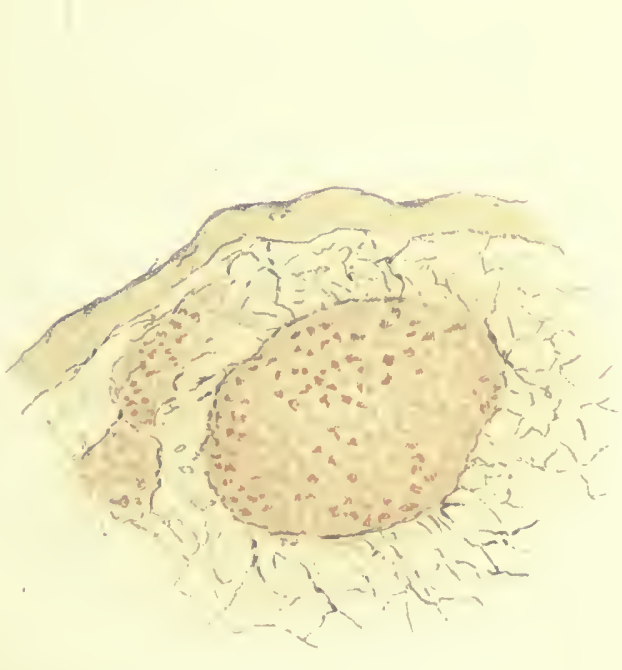

Fign 3
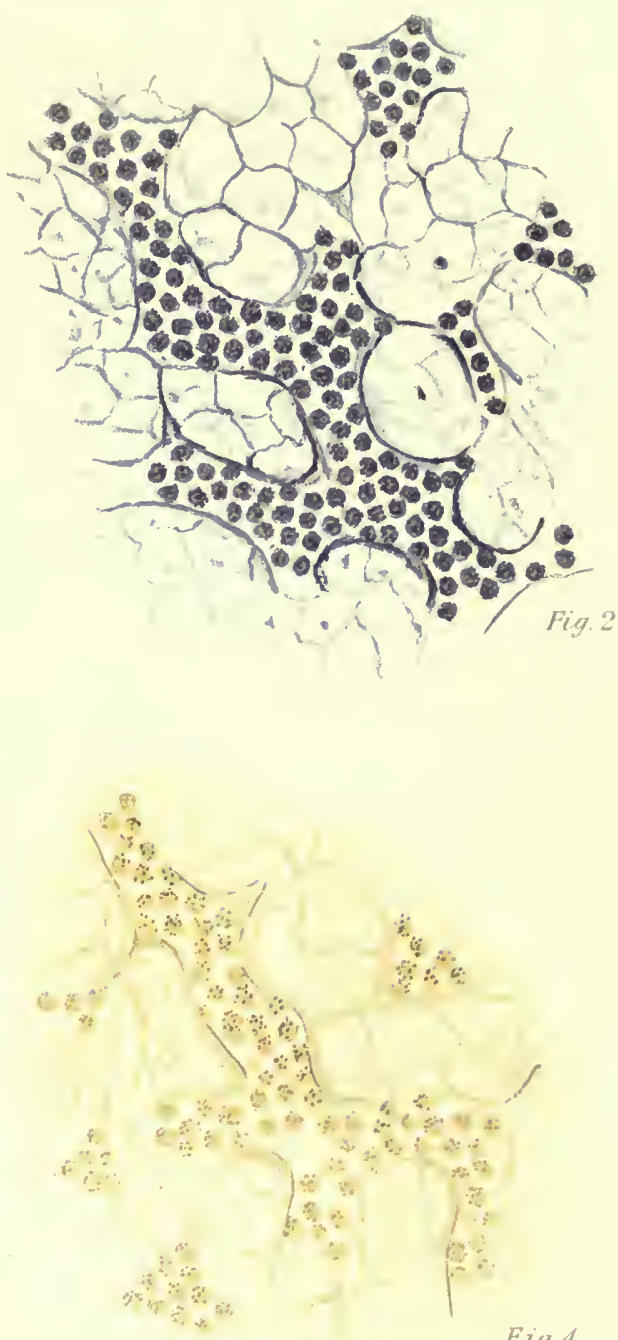

Fig. 4.

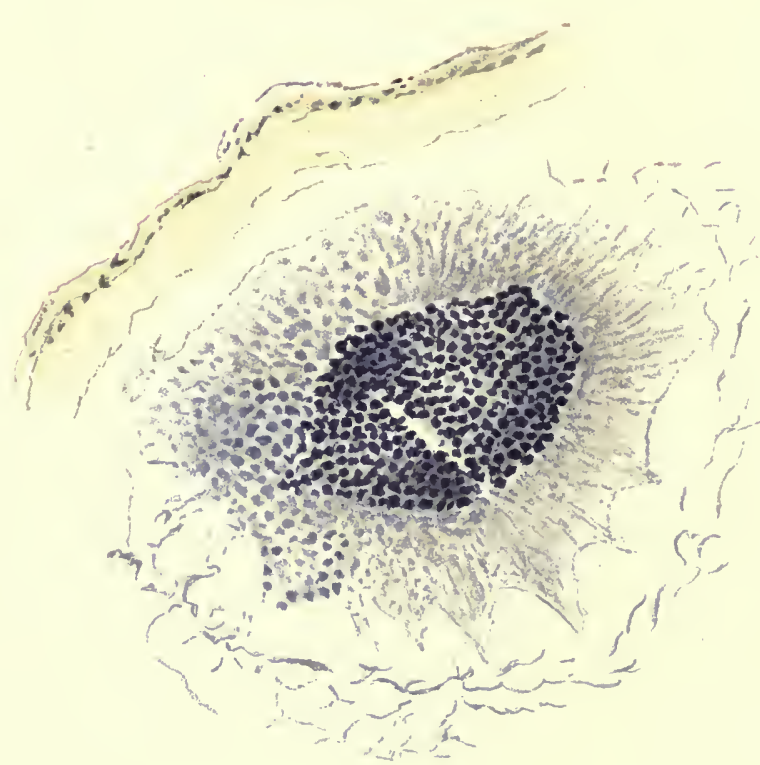




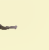


FOURTEEN DAY USE RETURN TO DESK FROM WHICH BORROWED

This book is due on the last date stamped below, or on the date to which renewed.

Renewed books are subject to immediate recall.

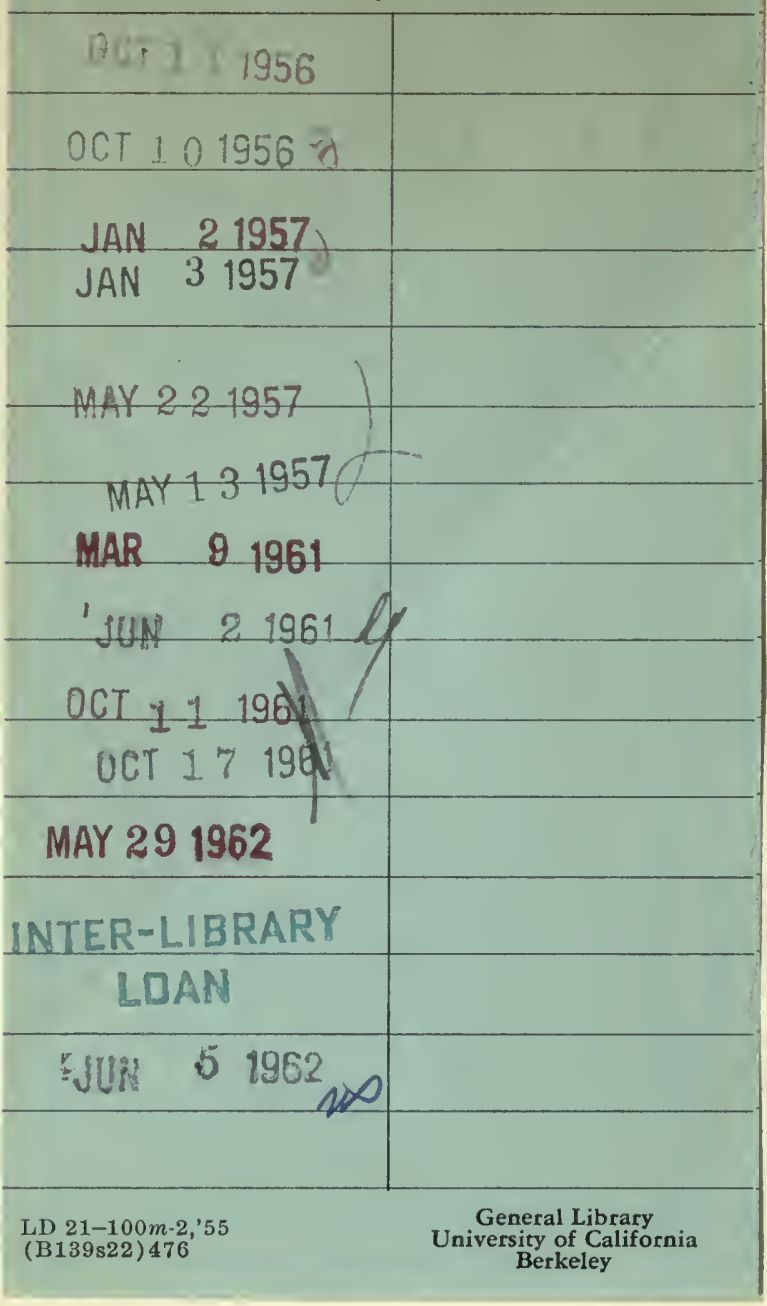


